\title{
THE PATENT OFFICE AS GUARDIAN OF THE PUBLIC INTEREST IN TRADE-MARK REGISTRATION PROCEEDINGS
}

\author{
Walter J. Derenberg**
}

\section{INTRODUCTION}

It is one of the declared purposes of the Lanham Trade-Mark Act of 1946 to confer upon the owner of a registered trade-mark a greater measure of security than was available under the predecessor acts. While the Act of 1905 was based on the theory that the Federal Government could not under the commerce clause of the Constitution enact legislation granting substantive statutory rights to the owner of a trade-mark, ${ }^{1}$ the new law is based on the presupposition that within the realm of commerce, as broadly defined in Section 45 of the Act, ${ }^{2}$ a federal registration statute may create substantive rights beyond the mere procedural advantages which resulted from registration under the previous acts. Outstanding among the sections of the new Act which create substantive rights are the constructive notice section (Section 22) and the incontestability section (Section 15 ). The latter, while subject to numerous exceptions, will protect the owner of a registered mark after the expira-

\footnotetext{
* Trade-Mark Counsel to the Commissioner of Patents; Associate Professor of Law, New York University. The views herein expressed are those of the author and do not necessarily reflect the vicws of the Patent Office.

${ }^{1}$ American Steel Foundries v. Robertson, 269 U. S. 372 (x926); United States Printing and Lithograph Co. v. Griggs, Cooper \& Co., 279 U. S. 156 (I929); American Trading Company v. H. E. Hcacock Co., 285 U. S. 247 (1932); Liddy, Has Congress the Constitutional Power to Legislate on the Substantive Law of Trade-Marks? 6 Fond. L. Rev. 408 (1937); Schechter, Fog and Fiction in Trade-Mark Protection, $3^{6}$ Coz. L. Rev. 60 (1936); Fathchild, Territoriality of Registered Trade-Marks, 3 IDnно L. J. 193 (1933); March, Territorial Scope of the Trade-Mcrk Act of 1946, 38 T. M. Rcp. 955 (1946); Diggins, Federal and State Regulation of Trade-Marks, this symposium, supra.

The Second Circuit Court of Appeals, in its decision in S. C. Johnson \& Son v. Johnson, 8I U.S.P.Q. 509 (1949), for the first time categorically held that the new act would "indeed put federal trade mark law upon a new footing." The court then said:

"The Act of 1905 had made the registration of a trade-mark only prima facic evidence of ownership, and the question must be regarded as never finally settled whether it created a substantive federal trade mark law, as distinct from the common law of the states, or whether it mercly gave jurisdiction to the district courts and certain procedural advantages to the owner. The Lanham Act put an end to any doubts upon that score, and to the confused condition in which those doubts involved the whole subject, especially after Eric Railroad Company v. Tompkins." Id. at $5 \mathrm{Ir}$.

${ }^{2}$ 60 STAT. 443, 15 U. S. C. $\$ 1 \times 27$ (1946). The definition reads: "The word 'commerce' means all commerce which may lawfully be regulated by Congress." This definition has recently becn held to be broad enough to permit injunctive relief even against a purcly intrastate infringer of a mark registered under the Act of 1905. Cole of California v. Collette of California, 79 U. S. P. Q. 267 (D. Mass. 1948); but see, for a contrary view, C. B. Shane Corp. v. Peter Pan Style Shop, 80 U. S. P. Q. 559 (N. D. Ill. 1949).
} 
tion of the required five-year period of use against belated attacks on the technical validity of the registered mark or the title of its owner. ${ }^{3}$

As a necessary corollary to a statute thus enlarging the trade-mark owner's rights, certain additional precautionary provisions safeguarding the public interest were incorporated in the new Act. It would seem axiomatic that a statutory régime such as that presently prevailing in most common-law countries, which treats the registration of a trade-mark not as a mere "deposit" but as a grant of a statutory privilege available only after careful pre-examination by the Patent Office, must require a much larger degree of administrative scrutiny with respect to the granting of registrations than would be necessary in countries, such as France, where trade-marks are merely "deposited" and where the validity and scope of the registrant's rights are left entirely to judicial determination. Such a "deposit" system prevails in the United States under the Copyright Act of rgog, but not under the Federal TradeMark Act. The more quasi-judicial powers are conferred by statute upon the administrative agency charged with the registration of trade-marks, and the broader the substantive legal effects which may flow from the allowance of applications for registrations, the greater and more important becomes the duty of those charged with the administration of the statute constantly to bear in mind and carefully to weigh the possible adverse effect of the registration on the public interest. It was not surprising, then, that shortly before the final enactment of the Act of 1946, it was asserted by the Antitrust Division of the Department of Justice ${ }^{5}$ that the Act as then written failed adequately to safeguard the public interest in numerous respects, and that in particular the provisions concerning incontestability should be restricted by certain limitations aimed at the prevention of monopolistic abuses of registered trade-marks. If the new Act as finally enacted is examined as to the extent to which the interest of the general public is recognized, it becomes apparent that the public interest has found statutory expression in two entirely different ways:

I. On the one hand, we find the principle stated and reiterated many times throughout the statute that no mark shall be registered or legally protected which would be likely to cause confusion or mistake in the public mind. This is, of course, the aspect of the public interest with which the Patent Office in registration pro-

${ }^{3}$ Ooms, Incontestability, this symposium, supra: Daphe Robert, The New Trade-Mark Manual 135 et seq. (1947); Derenberg, Trade Marks Under the Lanham Act, Fortune, Feb. 1949, p. 147; but of. Williamson, Trade-Marks Registered Under the Lanham Act Are Not Incontestable, Printers Ink, June 6 and June 13, 1947, reprinted in 37 T. M. Rep. 404 (1947).

- It has been suggested by eminent authority that a system of administrative examination similar to that now prevailing in case of patents and trade-marks should be substituted for our present copyright "deposit" system, under which the Register of Copyrights has been held to have, for the most part, ministerial functions only. Cf. letter to the Librarian of Congress concerning certain aspects of the Copyright Act of March 4, Ig09, by C. L. Bouvé, Register of Copyrights, Government Printing Office, 1938 , p. 53 et seq.

'Hearings before the Subcommittee on Trade-Marks of the House Committee on Patents, 77th Cong., 2d Sess. (I942); testimony of Ernest S. Meyers, id. at 35; testimony of Bartholomew Diggins, id. at 3; and testimony of Ellion H. Moyer, ibid. Also, Hearings before the House Committee on Patents on H. R. 82, 78th Cong., 2d Sess. (1944); testimony of Elliott H. Moyer, id. at 7I, 141. Cf. particularly the statement by the Department of Justice on H. R. 82 , with appendices, reprinted in full, id. at 58 et seg. 
ceedings is primarily concerned. As if to make certain that the Office should never lose sight of this duty, at least ten different sections of the new Act refer in one way or another to the protection of the public against possible deception. After requiring the Patent Office in Section 2(d) not to register any mark which may be confusingly similar to a previously registered mark or to a trade name previously used, the proviso permitting concurrent registrations immediately stresses again that such registration may be granted only after a determination by the Commissioner that "confusion or mistake or deceit of purchasers is not likely to result in the continued use of such marks ..." Sections 3 and 4 , which for the first time provide for the registration of service marks, collective marks, and certification marks, exclude from registrability any marks which may lead to confusion in the public mind as to certain representations made by the applicants therefor. Again, Section 5, which provides for registration of marks used by "related" companies, contains an exception with regard to applicants using the mark in such a manner as to deceive the public. Moreover, upon a suggestion by the representatives of the Department of Justice, Section 5 was limited to situations in which the mark is "legitimately" used by related companies, thereby apparently making it the duty of the Patent Office to scrutinize the legitimacy of the relationship between a parent and a subsidiary company, or that between a licensor and licensee. ${ }^{6}$ Section ro of the new Act, which greatly liberalizes the rigid assignment provision of Section 7 of the Act of $x 905$, immediately warns against any misuse of the mark by the assignee in such a way as to misrepresent the source of the goods or services in connection with which the mark is used. Such abuse is also made a ground for cancellation of a registration at any time (Section $\mathrm{I}_{4}(\mathrm{c})$ ). The same section for the first time authorizes the Federal Trade Commission to apply for cancellation of fraudulently obtained registrations. The provisions for opposition, interference, and cancellation proceedings generally reflect the same basic idea that no mark shall be registered or remain on the register which is likely to cause confusion in the public mind. It is thus clear that under the structure of the Lanham Act the safeguarding of the public interest plays a vital part in the administrative determination of any pending application as well as in all inter partes decisions in opposition, interference, or cancellation proceedings.

2. Protection of the public against likelihood of confusion or deception is not, however, the only aspect of the public interest involved in the registration and protection of trade-marks. Equally important is the interest of the public in not being deprived of the common use of words which are in the public domain. When, therefore, the new concept of an "incontestable" right was introduced into the new statute, it was deemed necessary expressly to provide that no incontestable right

\footnotetext{
${ }^{6}$ For a detailed discussion of the concept of related companies under the new act and its legal implicatons, of. Taggart, Trade-Marks and Related Companies: A New Concept in Statutory Trade-Mark Law, and Shniderman, Trade-Mark Licensing-A Saga of Fantasy and Fact, supra; Statement of Department of Justice on H. R. 82, supra note 5 , at 63 .
} 
should ever be acquired in a mark which is or has become a common generic term. ${ }^{7}$ It is further provided that in case of a formerly patented article a cancellation proceeding may be instituted at any time, incontestability notwithstanding, if the name has become a common descriptive term. Moreover, a number of provisions were added to safeguard the public interest against monopolistic abuses of trade-marks and certification marks. Specifically, it is now provided in Section 33(b) (7) that it shall be a defense in an infringement suit based on an otherwise incontestable trademark that it has been, or is being, used to violate the antitrust laws of the United States. ${ }^{8}$

The present article will not be concerned with those aspects of the public interest which center around these anti-monopoly provisions of the new Act. Nor will it add to the already voluminous literature discussing the legal requisites of trade-mark infringement. ${ }^{9}$ Rather, it will try to pose and examine the problems which daily confront the Patent Office in balancing the private interest of an applicant or a registrant against a possible adverse public interest. As will be shown hereafter, this problem is particularly difficult because of the indefinite and nebulous nature of the present "public interest" concept, and is beclouded by a failure to realize that the problem arises in greatly varied forms in three different stages of a registration proceeding: ( $I$ ) It is presented first when the Patent Office as administrative agency considers the registrability of a trade-mark ex parte under Section 2 of the Act; (2) it may again appear in a somewhat different form in the course of an opposition, cancellation, or interference proceeding when the Commissioner of Patents acts in a quasi-judicial capacity in determining a controversy between two or more private parties; (3) and it may enter into the picture for the third time in a still different form when the Commissioner no longer serves either as administrator or in a judicial capacity, but is sued in equity by an unsuccessful applicant after a final ex parte rejection, or is joined as a co-defendant in such action by the defeated party to an opposition or other inter partes proceeding.

${ }^{7}$ Section 15 (4) of the Lanham Act, 60 STAT. 433, 15 U. S. C. \$1064 (I946). The section inadvertently also includes "trade names" in the exception from incontestability although "trade names" as defined in $\$ 45$ are not registrable as trade-marks on the principal register. This part of $\$ 15$ was added in conference upon the suggestion of the representatives of the Department of Justice a few days before the bill was finally enacted.

${ }^{8}$ The significance of this proviso is fully discussed in Timberg, Trade-Marks, Monopoly, and the Restraint of Competition, this symposium, infra. It is also treated in detail in Mrlton Handler, TradeMarks and the ANTrtrust Laws, a lecture before the Practising Law Institute, New York, in a series entitled Trade-Marks and the Lanham Act, p. 225, reprinted in 38 T. M. Rep. 387 ( 1948 ). Cf. also Borchardt, Are Trademarks an Antitrust Problem? 3I Geo. L. J. 245 (1943); Taggart, Trade Marks: Monopoly or Competition? 43 MrCH. L. Rev. 659 (r945).

- Callmann, Trade-Mark Infringement and Unfair Competition, this symposium, supra. James F. Hoge, Trade-Mark Infringement (Practising Law Institute Lectures, supra note 8, at 93), reprinted in ${ }_{38}$ T. M. Rep. 400 ( 1948 ). Of the older literature, cf. Wolff, Non-Competing Goods in Trade-Mark Law, 37 Col. L. Rev. 582 (1937); Goble, Where and What a Trade-Mark Protects, 22 ILL. L. Rev 379 (1927); Oates, Relief in Equity Against Unfair Trade Practices of Non-Competitors, 25 Ill. L. Rev. 643 (1931); Schechter, The Rational Basis of Trademark Protection, 40 Harv. L. Rev. 8I3 (1927). The most recent discussion of this subject may be found in Lunsford, Trade-Mark Infringement and Confusion of Source: Need for Supreme Court Action, 35 VA. L. Rev. 214 (I949). Cf. also I HarRy D. Nims, The Law of Unfair Competition and Trade-Marks 667 et seq. (4th ed. 1947). 
It thus becomes necessary to examine separately the different forms in which the public interest becomes directly or indirectly involved in each of these three stages of a registration proceeding.

\section{II}

Consideration of the "Public Interest" in Ex Parte Proceedings

I. The new Act of 1946, like the predecessor statutes, does not affirmatively state what may be registered as a trade-mark on the principal register, but negatively provides that "no trade-mark by which the goods of the applicant may be distinguished from the goods of others shall be refused registration ... on account of its nature," unless the mark falls within one of a series of statutory prohibitions. Some of these prohibitions are absolute in character, while others are relative or "temporary." In the first category belong the provisions which prohibit the registration of immoral, deceptive, or scandalous matter, or marks comprising the flag or coat of arms. The prohibitions against registration of geographical or deceptive marks or surnames now fall into the second category; under Section $2(f)$ of the new Act such names may now be registered on the principal register if they have become distinctive of the applicant's goods. By thus giving statutory recognition to the old common-law doctrine of secondary meaning, the Act empowers the Commissioner of Patents to grant registrations in cases where the private rights of the trade-mark owner and the trade-mark significance of his mark have come to outweigh the interest of the public in the unrestricted use of an originally descriptive or geographical term. ${ }^{10}$

Where, on the other hand, an application for registration comes into possible conflict with prior rights of third parties (Section 2(d)), a much more difficult problem of proper evaluation and consideration of the public-interest aspects of such third-party rights arises. Section 2 (d) as now worded prohibits the registration of any mark "which so resembles a mark registered in the Patent Office or a mark or trade name previously used in the United States by another and not abandoned, as to be likely, when applied to the goods of the applicant, to cause confusion or mistake or to deceive purchasers ..." It is, of course, obvious that the paramount purpose of this provision is to protect the public from registration of marks which might result in a likelihood of confusion. But it is equally apparent that the extent to which such public interest should be recognized depends to a very large degree upon the scope of legal protection to which the owner of the conflicting registration is entitled.

2. Before we attempt to solve the problem of balancing public interest and private rights for the purpose of administering Section 2(d), attention should be called collaterally and briefly to the following new features of the section:

a. Most important of all: the new law has abolished the principle previously

${ }^{10}$ The absolute prohibition in $\$ 2(\mathrm{c})$ against registration of a particular living person's portrait or name without his or her consent is based on considerations of protecting a person's right of privacy rather than trade-mark law and is not relevant for the purposes of the present discussion. 
found in Section 5 of the Act of rg05, that in order to be rejected on the ground of likelihood of confusion, the applicant's and prior registrant's or user's goods must have "the same descriptive properties." Moreover, Section 30 of the new Act now makes it entirely clear that the Patent Office classification of goods shall be used only "for convenience of Patent Office administration, but not to limit or extend the applicant's rights." Consequently, the Office has now been granted very broad authority to consider the probability of confusion administratively and before the mark is published in the Official Gazette for opposition by third parties. It is, of course, true that the exceedingly broad interpretation given in recent years to the language, "same descriptive properties," by the Court of Customs and Patent Appeals in inter partes cases and by the equity courts in proceedings under Section 49I5 of the Revised Statutes, which will be discussed later in this article, ${ }^{11}$ had immediate repercussions with respect to the ex parte practice in the Patent Office. Thus, after it had been held that the use of the same or similar mark on soap and soap receptacles $^{\mathbf{1 2}}$ might result in likelihood of confusion and that "therefore" those goods constituted merchandise "of the same descriptive properties," the Office could no longer proceed to publish such marks in the Official Gazette, thereby leaving it to a potential opposer to raise the issue of likelihood of confusion. Similarly, after it had been held in contested cases that likelihood of confusion would result from simultaneous use of the same or similar mark on coffee and canned fruit respectively, ${ }^{13}$ or on wearing apparel on the one hand, and children's hats and blouses and similar articles on the other, ${ }^{14}$ the Office was, of course, bound to cite as references ex parte any previously registered marks falling within such related classes. The Office was also bound to adjust its practice to the result of the famous Yale decision, ${ }^{15}$ in which the Circuit Court of Appeals, speaking through Judge Learned Hand, held in a 4915 proceeding involving an application to register the name "Yale" for electric batteries that the language "same descriptive properties" should be given no more than lip service in situations in which confusion of the public would result and in which, consequently, the applicant, even if he were successful in the Patent Office, could be sued as an unfair competitor. The court said:

While we own that it does some violence to the language, it seems to us that the phrase should be taken as no more than a recognition that there may be enough disparity in character between the goods of the first and second user as to insure against confusion. That will indeed depend much upon trade conditions, but these are always the heart of the matter in this subject ... We cannot say that that is the case here, for the fact that flashlights and locks are made of metal does not appear to us to give them the same descriptive properties except as the trade has so classed them. But we regard what the trade thinks as the critical consideration, and we think the statute meant to make it the test, despite the language used. ${ }^{16}$

\footnotetext{
${ }^{11}$ See Part IV, infra.

${ }^{12}$ Elgin American Mfg. Co. v. Elizabeth Arden, Inc., 83 F. $2 d$ 68x (C. C. P. A. 1936).

${ }^{13}$ California Packing Corp. v. Tillman \& Bendel, 40 F. $2 \mathrm{~d} 108$ (C. C. P. A. 1930).

${ }^{14}$ B. F. Goodrich Co. v. Hockmeyer, 40 F. 2 d 99 (C. C. P. A. 1930).

15 Yale Electric Corp. v. Robertson, 26 F. $2 d 972$ (C. C. A. 2d 1928).

16 Id. at 974 .
} 
This was the first case in which a court, even under the old law and handicapped by the language "same descriptive properties," came to the conclusion in an equity proceeding under Section 4915 that the Office in appropriate cases should give consideration to a prior registrant's or user's equities as a matter of discharging its duty toward the public. The case was thus the first step toward the realization that to some extent a proper consideration of the public interest might require the application of principles of unfair competition by the Patent Office.

As this article goes to press, the Court of Appeals for the Second Circuit has just held, squarely and for the first time, that the theory laid down in the Yale case has become statutory law under the new Act. In the majority opinion, Judge Learned Hand, while refusing to grant more drastic relief to the plaintiff than had been previously awarded ${ }^{16 x}$ because of the peculiar circumstances of this case and particularly the weakness of the mark involved, said:

It is quite enough to explain the change of diction in the Lanham Act that Congress wished to do no more than clear up this doubt-if indeed it was not more than a doubt -and make the protection of the new right coextensive with the law of unfair competition as it was in 1946 , just as the Act of 1905 had made it coextensive with the law of 1905. Besides, not only is this a sufficient reason for the change, but there is the strongest possible reason for not reading the language literally, because to do so would frequently result in great hardship to others, and give to the first user of a mark a wholly unjustified power to preempt new markets. ${ }^{16^{b}}$

It is true that Judge Hand then continued to say that not even the law of unfair competition as of 1946 would justify the granting of more drastic relief to the plaintiff, while Judge Clark, in a dissenting opinion, expressed the view that under the Lanham Act the previous case should be reopened for the purpose of awarding an opportunity to the plaintiff to show that the previous decree had not eliminated but had in effect increased confusion in the public mind with regard to the use by the defendant of the name "Johnson's." But the quoted statement and the majority opinion certainly pave the way for a much more general recognition of principles of unfair competition in trade-mark registration proceedings than has been the practice under the Act of 1905 .

Before we discuss the implications which will follow from the adoption of this new concept in Section 2(d) of the Lanham Act, reference should be made in passing to a few other noteworthy features of Section 2(d).

b. It is significant to note that the type of likelihood of confusion which is to be considered by the Office ex parte is not surrounded by any limiting words whatsoever, while such words of limitation do appear in the infringement section (Section 32). The latter section requires a finding of confusion or mistake or deception of purchasers "as to the source of origin" of the goods or services. The quoted language does not appear in Section 2(d). It was because of these limiting

rox S. C. Johnson \& Son v. Johnson, II6 F. 2d 427 (C. C. A. $2 \mathrm{~d} 1940$ ).

${ }^{10 b}$ S. C. Johnson \& Son v. Johnson, 8I U.S.P.Q. 509, 513 (C.C.A. 2d 1949). 
words that the Circuit Court of Appeals for the Seventh Circuit in a much criticized decision held that the simultaneous use of the well-known "Sunkist"17 trade-mark by a baker on raisin bread was not likely to cause confusion as to "source of origin" of the goods, and that indeed the test for infringement under the new Act was not as broad as it had been under the Act of 1905, even though any reference to goods of the same descriptive properties had been eliminated from the infringement section. It would seem that the Patent Office in administering the new Section 2(d) should not necessarily be guided by the ruling in the Sunkist case, since the critical restrictive language which the court used as the basis of its decision is not repeated in Section 2(d). In other words, a consideration of the public interest as an ex parte matter might go beyond the measure of protection to which the prior registrant or owner may be held entitled in private litigation. It would seem rather doubtful, moreover, whether other courts would follow the interpretation of Section 32 by the Court of Appeals in the Sunkist case, since the entire history of the Lanham Act negatives the court's conclusion that the infringement test was narrowed rather than broadened by the new Act. ${ }^{17^{*}}$

c. Section 5 (b) of the old Act prohibited registration of marks which were identical with or similar to "a registered or known trade-mark owned and in use by another ..." In a separate proviso, it also prohibited the registration of any mark which consisted merely of the name of a corporation or firm. The new Act in combining these two provisions prohibits registration of an identical or confusingly similar mark over "a mark or trade name previously used in the United States by another and not abandoned." This deliberate change in language has already led to three new policies which should not be overlooked in connection with the problems here discussed:

(I) Corporate names as such no longer enjoy the anomalously broad protection to which they were held entitled under the langauge of the old Act. Without going into detail here, suffice it to say that under the Act of 1905 the mere filing of a certificate of incorporation with the Office-hundreds of such certificates are still on file-led to an ex parte rejection of any subsequent application which included the full corporate name of the corporation, regardless of whether an entirely different line of merchandise was involved and irrespective even of the fact that the subsequent applicant may have used his mark prior to the date of incorporation. ${ }^{18}$ Under the new Act, corporate names no longer enjoy such a privileged position.

${ }^{17}$ California Fruit Growers Exchange v. Sunkist Baking Co., $x 66$ F. 2d 97r (C. C. A. 7th 1947); cf. Notes, 48 CoL. L. REv. 648 (1948), I6 GEo. WASH. L. Rev. 589 (x948); Callmann, The "Sunkist" Decision: Trade-Marks at the Crossronds, 38 T. M. Rep. 304 (1948).

${ }_{17 a}$ The majority opinion in the Johnson case, stipra note $16 \mathrm{~b}$, is clearly based on the assumption that the infringement test under the new Act has been broadened. No reference at all.is found in that opinion to the Stunkist case, supra note 17 , and the dissenting judge refers to it only as indicating the different interpretations to which the term "likelihood of confusion" has been and is being subjected."

${ }^{18}$ Walter J. Derenberg, Trade-Mark Protection and Unfair Trading 637 et seq. (1936). At the present time the Patent Office still accepts articles of incorporation for filing purposes, but these are used as references only against applications which are still pending under the Act of 1905. They will not be cited against applications filed under the new Act. 
Under Section 2(d) a previously used corporate name will not be cited against a new applicant unless a likelihood of confusion exists-just as in cases of trade-marks proper. From the viewpoint of protecting the public interest, it was never clear why adoption of someone else's corporate name should have constituted an absolute ground of rejection while a previously owned trade-mark was cited only in cases where a likelihood of confusion might result. ${ }^{19}$

(2) As a result of this change, the Office is not likely to cite previously used trade names ex parte, although it has statutory authority to do so. It was suggested many times during the hearings ${ }^{20}$ that even under the old Act the usual practice was, or should have been, to pass marks which might have embodied someone else's trade name to opposition. It is likely that as a matter of administrative expediency no particular search will be made by the Patent Office as to the possibility of a conflicting firm or corporate name, although reliance may, of course, be placed on such names by opposing parties subsequent to publication in the Official Gazette.

(3) The change of language from "previously owned" to "previously registered" has also resulted in abandonment of the practice which had prevailed at the Patent Office following the Commissioner's decision in the Essex Rubber Company case $^{21}$ not to cite previous registrations under the Act of 1920 against new applications under the 1905 Act. The basis for this rule, which reduced registrations under the I920 Act to not much more than "hybrids," was that a certificate issued thereunder was not even prima facie evidence of "ownership" of the mark, and, therefore, would not come within the language "previously owned." Under the new Act, registrations under the Act of 1920 or on the new supplemental register are being cited as references by the Office against new applications because the change in language from "previously owned" to "previously registered" was embodied primarily to overcome the effects of the Essex Rubber case.

3. Against this new statutory background, we can now revert to an examination of the principal question with which this study is concerned, i.e., the determination of the issue of likelihood of confusion by the examining corps of the Trade-Mark Division on a strictly ex parte basis. It goes without saying that under the old Act all decisions of the Court of Customs and Patent Appeals in either inter partes or ex parte cases bearing on the presence or absence of same descriptive properties and on likelihood of confusion became immediately controlling precedents with regard to

${ }^{10}$ American Steel Foundries Co. v. Robertson, supra note I; Holly Molding Devices v. Esquire, Inc., 148 F. 2 d 355 (C. C. P. A. 1945) ("Esquire" for hamburger molding machine held unregistrable upon opposition by Esquire magazine). Cf. also Ex parte Brown \& Williamson Tobacco Corp., 68 U. S. P. Q. 21 (C. P. 1945) ("Life" for cigarettes held unregistrable although in use prior to the incorporation of Life magazinc). Cf. Skol Co., Inc. v. Olson, I5I F. 2d 200 (C. C. P. A. 1945), and Safeway Stores, Inc. v. Safeway Opticians, Inc., 68 U. S. P. Q. 332 (1946).

${ }^{20}$ Testimony of Edward S. Rogers in Hearings before the Subcommittee on Trade-Marks of the House Committee on Patents on H. R. 4744, 76th Cong., 2d Sess. 42 (1939); Hearings before the Sub. committee on Trade-Marks of the House Committee on Patents on H. R. 904t, 75th Cong., 3d Sess. 85 (r938).

${ }^{21}$ Ex parte Essex Rubber Co., 47 U. S. P. Q. 189 (1940). Pearne and Crotty, Trade-Mark Registration and the Lankam Bill, 23 J. PAr. OFF. Soc'y 58 et seq. (1941). 
subsequent administrative determinations ex parte. On the other hand, it was never considered permissible under the narrow language of the old Act to give ex parte consideration to principles of unfair competition (nor were these principles applied, as will be shown hereafter, ${ }^{22}$ in the ordinary opposition, cancellation, or interference proceeding). In other words, if an applicant applied to register the word "Kodak" for bicycles, ${ }^{23}$ or the words "Lady Esther" for tableware, ${ }^{24}$ or the word "Waterman" for razor blades, ${ }^{25}$ the Office had no alternative but to publish such marks and institute opposition proceedings upon request of the manufacturer of the well-known camera, cosmetics, or fountain pen. If no opposition was filed, the marks had to be registered. Under the Lanham Act, however, this question may be asked: If it is true that the Act was intended to confer broad jurisdiction upon the Patent. Office to apply certain equitable considerations of unfair competition in trade-mark registration proceedings, would it be beyond the province of the Commissioner under Section 2(d) of the new Act to reject applications such as "Lady Esther" for tableware ex parte? Or has the Office performed its duty of protecting the public against confusion if it publishes such marks for opposition in the expectation that a private party whose interests might be adversely affected by the registration will file an opposition? The answer to this basic question is especially difficult at the present time for two reasons:

a. In the first place, our courts are not in agreement on the extent to which equitable relief should be available in situations not involving "competition" in the narrower sense of the word but involving what has been frequently called "confusion in the wider sense." ${ }^{28}$ This is not the place to offer a detailed discussion of the various types of situations in which relief has been granted in different jurisdictions. Suffice it to restate here briefly that the necessity for injunctive relief in cases not involving mere passing off or mere confusion of goods has been recognized to a larger or smaller extent in the following situations: ( $I$ ) It is now well settled in this country-to quote Judge Learned Hand's language in one of the famous cases-"that a trade-mark protects the owner against not only its use upon articles to which he has applied it, but upon such other goods as might naturally be supposed to come from him."27 In other words, the pre-emptive right of a trademark owner to a natural expansion of his business must be borne in mind. (2) In a long series of decisions, it has been established that the scope of such pre-emptive right depends to a large extent on the "strength" or "weakness" of the mark involved. $^{28}$ (3) In numerous cases ${ }^{29}$ relief has been granted not on the basis of pre-

${ }^{22}$ Sce Part III of this paper.

${ }^{23}$ Eastman Kodak Co. v. Kodak Cycle Co., 15 Rep. Pat. Cas. 105 (1898) (use of the mark "Kodak" en bicycles enjoined).

24 Cf. In te Ben Brande, infra note 39.

${ }^{25}$ L. E. Waterman Co. v. Gordon, 72 F. $2 d 272$ (C. C. A. $2 d$ 1934) (use of the name "Waterman" enjoined with regard to razor blades).

${ }^{20}$ Wolff, supra note 9 , at 588 .

${ }^{27}$ L. E. Waterman Co. v. Gordon, 72 F. $2 d 272,273$ (C. C. A. 2d 1934).

28 "... . the rule that coined or fanciful marks or names should be given a much broader degree of 
serving an expected area of business for the trade-mark owner, but for the purpose of protecting him against confusion as to sponsorship or reputation. The most striking recent application of this principle may be found in the Seventeen cases, in which the owner of the magazine was granted injunctive relief against defendants who were using the mark " $I 7$ " on non-competing goods, i.e., girdles and dresses. Judge Augustus Hand, speaking for the majority in the later case, said:

It is settled law that a plaintiff who has established a right to a trade name which is fanciful or arbitrary or has acquired a secondary meaning is entitled to protection of his reputation against the use of that name by others even upon non-competing goods, if the defendant's goods are likely to be thought to originate with the plaintiff... We can see no reason why the principle laid down by the foregoing decisions does not apply to the situation of confusion as to sponsorship found by the district judge to exist in the record before us. In either case, the wrong of the defendant consisted in imposing upon the plantiff a risk that the defendant's goods would be associated by the public with the plaintiff, and it can make no difference whether that association is based upon attributing defendant's goods to plaintiff or to a sponsorship by the latter when it has been determined that plaintiff had a right to protection of its trade name. In each case the plaintiff is likely to suffer injury to his reputation and his trade name..$^{30}$

(4) Ever since the late Dr. Frank Schechter's article on "The Rational Basis of Trade-Mark Protection,"31 the concept of protecting a trade-mark against "dilution" has found gradual recognition in this country. It was this concept that led the New York court to grant relief to the owners of the "Tiffany" trade-mark against use of that famous name on motion pictures. ${ }^{32}$ The significant aspect of this "anti-

protection than words in common use is sound, for it recognizes not only the orthodox basis of the law of trade-marks that the sale of the goods of one manufacturer or vendor as those of another should be prevented, but also the fact that in modern business the trade-mark performs the added function of an advertising device, whose value may be injured or destroyed unless protected by the courts." Arrow Distilleries v. Globe Brewing Co., rr7 F. $2 \mathrm{~d} 347,35$ r (C. C. A. $4^{\text {th }}$ 1941). For further illustrations, cf. Derenburg, op. cit. supra note 18 , at 408 et seq., and II Rudolf Callmann, The law op Unuain Contemtition and Trade-Maris 1226 et seq. (1945).

The significance of "fabricated trade-marks" has won final recognition in the Jolunson case, supra note $16 \mathrm{~b}$, where at the end of the majority opinion the following language is found:

"If Congress really meant to allow every first user of a mark so to stifle all excursions into adjacent markets upon showing no more than that confusion would result, it seems to us that it would have said so more clearly. In the case of fabricated marks which have no significance, sat'e as they denote a single source or origin of the good's to which they arc attached, the first user's right mity indecd go so far. The second user can then show no interest of his own; and if, as will then appear, his only purpose is to trade on the first user's good-will, it is indeed time to intervene. That situation is polar to this, and we do not believe that both have been swept into a common condemnation by the language used to create a new federal right." (Italies supplied.)

${ }^{20}$ Derenberg, op. cit. supra note $\times 8$, at $4 \mathrm{I} 9$. Lunsford, supra note 9, at $2 \times 8$ and cases cited. In one isolated case under the old Act, confusion as to reputation was even held a sufficient basis for sustaining an opposition proceeding. Imperial Cotto Sales Co. v. N. K. Fairbanks Co., 270 Fed. 686 (App. D. C. rg2r).

${ }^{30}$ Hanson v. Triangle Publications, Inc., I63 F. $2 \mathrm{~d} 74$ (C. C. A. 8 th 1947), cert. denied, 332 U. S. 855 (1948); Triangle Publications, Inc. v. Rohrlich, 167 F. 2d 969, 972-973 (C. C. A. 2d 1948).

${ }^{31}$ See note 9 supra.

32 Tiffany \& Co. v. Tiffany Productions, Inc., 264 N. Y. S. 459, I 88 N. E. 30 (1932). The dilution concept found recent statutory recognition in an amendment to the Massachusetts statute which now contains the following provision:

"Likelihood of injury to busines reputation or of dilution of the distinctive quality of a trade 
dilution" doctrine is that its applicability does not depend on the merits or demerits of the defendant's merchandise. In other words, Professor Brown's ${ }^{33}$ observations that protection against confusion as to reputation would become irrational in situations in which there is neither proof nor even an allegation to the effect that the defendant's merchandise or services were in fact inferior to those offered by the plaintiff in an unrelated field would lose their force if the anti-dilution theory of the Massachusetts $\mathrm{Act}^{34}$ or the Tiffany case is applied. In jurisdictions in which preservation of the uniqueness of a trade-mark may be recognized as necessary for the protection of the owner's property right in the mark, not even confusion as to sponsorship or reputation need be present in order to justify equitable relief.

b. Were it possible to look upon the various aspects of the "confusion" concept exclusively from the viewpoint of protecting private interests, the answer to the problem previously posed, i.e., which, if any, of these principles the Patent Office should consider on an ex parte basis, would be comparatively simple: we would have to conclude that injury to the reputation of a trade-mark owner's business or confusion as to sponsorship and similar issues are matters which might be properly raised in an inter partes proceeding by the injured party but which do not involve an issue of public interest for consideration by the Patent Office regardless of the attitude of the injured party. However, the answer is by no means as obvious as that. There are certain recent developments which seem to have so enlarged the concept of "public interest" that even issues which clearly fall within the realm of one of the above-mentioned four categories of unfair competition have come to be considered as matters of public concern at the same time. A striking illustration of an

name or trade-mark shall be a ground for injunctive relief in cases of trade-mark infringement or unfair competition notwithstanding the absence of competition between the parties or of confusion as to the source of goods or services." Mass. GEN. LAws c. Iro, \$7A, approved May 2, r947.

In what appears to be the first judicial interpretation of the Massachusetts Act, Judge Wyzanski, in discussing the scope of protection to which the owner of the trade name "Food Fair" was entitled, said:

"The first of these two new substantive rights is protection against "likelihood of injury to business reputation.' If one were to read that phrase without any acquaintance with the prior case law and the mischief sought to be remedied, it would be possible to construe it as affording protection only in a case where it was probable that defendant would render inferior services or sell inferior goods which would make customers think less of plaintiff. That is, plaintiff would be required to show-what has not been shown at bar-that defendant's services or goods were below plaintiff's standard. Cf. Frank, 'J., concurring in Standard Brands v. Smidler, I5I F. 2 d 34,43 (C. C. A. 2) (66 U. S. P. Q. $337,345-6$ ) commented on by Ralph S. Brown, Jr., 57 Yale L. J. at 1194. But such a literal reading is not warranted because the statute was obviously designed to make the Massachusetts law go at least as far, as the unfair competition rules laid down in federal courts before the Erie case and as far as the Restatement of Torts. ...

"The second new substantive right is also applicable. It accords protection against 'likelihood of dilution of the distinctive quality of a trade name.' The position in this phrase of the adjective 'distinctive' shows that what is protected is not merely a distinctive trade name such as a coined word but also the essential or characteristic quality inherent in any valid trade name after it has acquired a distinct secondary meaning." Food Fair Stores, Inc. v. Food Fair Inc., 79 U. S. P. Q. II4, II9 (D. Mass. 1948).

${ }^{33}$ Brown, Advertising and the Public Interest: Legal Protection of Trade Symbols, 57 Yale L. J. Ir65, 1194 (1947).

${ }^{34}$ Standard Brands, Inc. v. Smidler, 15I F. $2 d$ 34, 42 (C. C. A. 2d 1945) (concurring opinion). 
almost complete overlapping of "public" and "private" interest in cases of this kind may be found in a comparison of a series of private litigations instituted by the manufacturer of the "Lady Esther" cosmetics on the one hand, and a recent cease and desist order issued by the Federal Trade Commission under Section 5 of the Federal Trade Commission Act against the owner of the registered trade-mark "Lady Esther" for silverware, on the other. Indeed, it may be candidly stated that it was this recent Federal Trade Commission order and the legal implications which may flow from it with respect to the administration of the Trade-Mark Act by the Patent Office which served as the primary inspiration for the present study.

The well-known trade-mark "Lady Esther" as used on cosmetics has been the subject of much litigation. In I943, the Illinois court granted relief in equity to the cosmetics manufacturer against a defendant's use of the "Lady Esther" name in connection with its "Lady Esther Corset Shoppe, Inc." The decision was particularly noteworthy because it marked the first clear deviation by the Illinois state courts from the strict "passing off" rule. There was admittedly no direct competition between the parties, but the court thought that the public might be led to believe that there was "some connection" in trade between the plaintiff and the defendant companies. It said:

And the good-will of plaintiff, which it had built up at great expense over a period of years, would be whittled away. Courts of equity ought not to be so feeble as to be unable to prevent this. ${ }^{36}$

The court also specifically mentioned that its decision was in harmony with the holdings of seven other cases in which "Lady Esther" had been previously protected in equity against use on hosiery, women's clothing, jewelry, gloves, and other articles. ${ }^{37}$ Subsequent to its victory in the Illinois court, the same concern brought a civil action for infringement in the Federal District Court of Rhode Island in 1942 seeking an injunction against the defendant's use of the "Lady Esther" name in connection with a shoe business. It appeared that the defendant operated a shoe store in Providence, Rhode Island, under that name. Since he had adopted not only the trade name "Lady Esther" (on the alleged ground that it was the nickname of his son's wife), but had also copied the peculiar script used by the plaintiff, his use of the name was held to be likely to cause confusion. The plaintiff was granted an injunction. ${ }^{38}$ It thus appears clear beyond doubt that the owner of the "Lady Esther" mark was held entitled to equitable relief not only as against actual competitors, but against third parties whose simultaneous use of the name may have

${ }^{35}$ Lady Esther, Ltd. v. Lady Esther Corset Shoppe, Ine., 317 Ill. App. 451, 46 N. E. 2d I65 (1943); cf. comprehensive annotation in 148 A. L. R. 6 .

${ }^{30} 46$ N. E. $2 d \times 65,169$ (1943).

${ }^{37}$ The owners of the "Lady Esther" mark were also successful in obtaining cancellation of a trademark "Lady Esther" registered in $x 935$ for a California concern which subsequently consented to the cancellation of the mark. ("Lady Esther," T. M. No. 320,838, registered Jan. 8, 1935, cancelled May 9. $194 \mathrm{I}$, for use on hosiery, pajamas, underwear, etc.).

${ }^{38}$ Lady Esther Ltd. v. Flanzbaum, 44 F. Supp. 666 (D. R. I. 1942); cf. Note, 27 B. U. L. Rzv. $489(x 947)$. 
resulted in injury to plaintiff's reputation or in confusion as to sponsorship. Even in the traditionally most conservative state courts of Illinois, such relief on principles. of unfair competition was granted. In the light of this respectable line of decisions protecting the "Lady Esther" trade-mark, it would seem at first blush that the Patent Office would fully discharge its duty toward the public in a case in which a new applicant may apply for registration of "Lady Esther" for, let us say, neckties, if it published such mark for opposition in the expectation of a showing of injury by the cosmetics manufacturer in an opposition proceeding. No over-riding aspect of the public interest would seem to be involved thus far. However, the protection of the "Lady Esther" trade-mark recently also became a matter of concern for the Federal Trade Commission. While the available records do not indicate whether the Commission's complaint was filed upon the suggestion of the trade-mark owner himself or upon a complaint by a member of the public, the fact remains that in June, I943, a complaint was issued against a certain Ben Brande, ${ }^{39}$ under Section 5 of the Federal Trade Commission Act, charging him with improper use of the "Lady Esther" mark in connection with the manufacture of cheap silverware. The respondent, by using advertisements such as, "Get this beautiful Lady Esther Design Silverware Set," was charged to have misled the public into believing that his products originated with the well-known and prominent cosmetics concern identified in the public mind with the name "Lady Esther." In November, I948, the Commission issued its order enjoining respondent from using the words "Lady Esther" with regard to tableware and similar products. After stating that the name "Lady Esther" had become famous as the cosmetics manufacturer's trade-mark and enjoyed wide and favorable reputation, the Commission found:

By the use on his products, and in his literature of the trade-mark "Lady Esther," the respondent has created in the minds of the purchasing public much confusion and misunderstanding as to the origin, value and quality of his products. Because of the public's long familiarity with the trade-mark "Lady Esther," and the tendency of many individual members of the public to associate such trade-mark with the Lady Esther Company, Ltd., such members of the public, upon seeing the name used on and in connection with the respondent's products, are led to believe that such products are manufactured by and are the products of the Lady Esther Company, Ltd. ${ }^{40}$

The Commission also stated in paragraph seven of its findings that the respondent's tableware was not of the quality and did not give the performance which the purchasing public ordinarily expected to receive in purchasing products marked "Lady Esther." The conclusion was then reached that the defendant's use of the trademark resulted in "prejudice and injury of the public." $\$ 1$

The Lady Esther case is, of course, not the first trade-mark infringement case in which the Federal Trade Commission detected a sufficiently important public interest to justify its intervention. The Commission many years ago took jurisdiction in a

\footnotetext{
${ }^{30}$ In re Ben Brande, an individual trading as Sales Stimulators, Docket No. 4982 (1948).

${ }^{40}$ Id. 96, p. 3 .

41. p. 4 .
} 
case of this type in the now famous Klesner case, ${ }^{42}$ involving an allegedly unfair and unauthorized use of the name "Shade Shop." It was in that celebrated case that Mr. Justice Brandeis, speaking for the Supreme Court, denied the Commission's right to proceed in cases in which "the protection of the public is an incident of the enforcement of a private right." The opinion said:

But to justify the Commission in filing a complaint under section 5, the purpose must be protection of the public. The protection thereby afforded to private persons is the incident. Public interest may exist although the practice deemed unfair does not violate any private right ...

In determining whether a proposed proceeding will be in the public interest the Commission exercises a broad discretion. But the mere fact that it is to the interest of the community that private rights shall be respected is not enough to support a finding of public interest. To justify filing a complaint the public interest must be specific and substantial. ${ }^{43}$

Under the rule of the Klesner case, the finding of a specific and substantial public interest became a jurisdictional prerequisite which, if challenged in court, had to be proved by the Commission. However, in some subsequent cases the Klesner rule seems to have been somewhat relaxed. Thus, it was held in Parke, Austin \& Lipscomb, Inc. v. Federal Trade Commission ${ }^{44}$ that the trial examiner did not have to make a specific finding with regard to the requisite public interest. The court there said:

The question of public interest is a matter upon which the Commission was competent to pass and it is sufficient for present purposes that the complaint alleged the existence of a public interest which the proof shows was necessarily involved in the merits of the case. $^{45}$

Under the rule of this case, no specific finding as to the presence of a public interest need be made so long as it is alleged in the complaint. ${ }^{46}$ In the meantime, the Commission had been sustained in a case in which an order had been issued against use of the name "Remington" on radio sets. ${ }^{47}$ The court agreed with the Commission that the name was selected by the respondent "because of contemplated advantage by lessening or otherwise injuring the business of present or potential rivals." "We are of the opinion," said the court, "that the purchasing public is

${ }^{42}$ Federal Trade Commission v. Klesner, 280 U. S. I9 (1920).

${ }^{13}$ Id. at $27,28$.

" I42 F. $2 d 437$ (C. C. A. $2 d$ I944).

45 Id. at 441 .

${ }^{40}$ On the other hand, it was said in the more recent case of S. Buchsbaum \& Co. v. Federal Trade Commission, I6o F. 2d I21, 123-124 (C. C. A. 7th 1947), contrary to the holding of the Parke casc:

"However, even though there be no proof of actual deception required, there must be a showing that the acts and practices sought to be proscribed are detrimental to the public interest in order to satisfy the statutory requirement that the proceeding be in the public interest. 15 U. S. C. A. $\$ 45$ (b). Here the Commission made no finding that the deception, if any, had ever resulted in or had any tendency to result in detriment to the purchasing public. We find nothing in the findings to support the conclusion that the acts and practices are all to the prejudice and injury of the public." "

${ }^{27}$ The Pep Boys-Manny, Moe \& Jack v. Federal Trade Commission, I22 F. $2 \mathrm{~d}$ I58 (C. C. A. $3 \mathrm{~d}$ 1941). 
entitled to be protected against the species of deception practiced by the petitioner and that its interest in such protection is specific and substantial." ${ }^{48}$ It was stressed in the Remington case that the purchasers of some $5^{800}$ radios over a number of years might have been deceived into purchasing an article which they might not have bought if clearly informed as to its origin. ${ }^{49}$

On the other hand, in November, 1947, the Commission issued a "Statement of Policy" which, it is submitted, cannot be easily reconciled with the course subsequently taken in the Lady Esther case. This Statement of Policy as to private controversies reads as follows:

It is the policy of the Commission not to institute proceedings against alleged unfair methods of competition or unfair or deceptive acts or practices where the alleged violation of law is a private controversy redressable in the courts, except where said practices tend to affect the public. In cases where the alleged injury is one to a competitor only and is redressable in the courts by an action by the aggrieved competitor and the interest of the public is not involved, the proceeding will not be entertained. ${ }^{51}$

If the Lady Esther case is examined in the light of this Statement of Policy, it is not immediately apparent why it should not have been considered as one of those

${ }^{48} \mathrm{Id}$. at $\mathrm{r} 6 \mathrm{r}$.

${ }^{\circ}$ While the Commission may have instituted numerous other proceedings based on trade-mark infringement, apparently so such case has reached the courts on appeal since the Remington case was decided. Nor has the respondent in the Lady Esther case, so far as the writer is informed, filed an appeal from the Commission's order. A comment upon the Remington case in $4 \mathrm{r}$ CoL. L. REv. 1457, $1459-$ I 460 (I94T) states:

"In thus failing to adhere to the Klesner holding on virtually identical facts, the instant case is a striking cxample of the recent judicial tendency to recognize 'public interest' in a wide variety of cases; it also marks the accompanying shift in emphasis from the competitor to the consuming public. Another effect is to be noted. In trade-mark simulation cases (such as the present) the public interest is hardly as immediate and apparent as in certain other cases of unfair competition where jurisdiction has been denied. It may therefore be presumed that the instant case, if accepted, will pave the way for a broader expansion of the Commission's powers." Cf. also McAllister, Basic Trends in Progress of Federal Trade Commission Act, ANTITRust Law Symposium 95 (Commerce Clearing House, Inc., 1949).

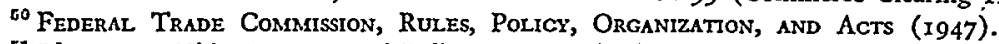

"1 Id. at 35. This Statement of Policy seems to be in complete accord with the statements of those who witnessed the early history of the Commission and the enactment of its organic act. Mr. Nelson B. Gaskill, in a paper entitled Public Interest Versus Private Interest in the Federal Trade Commission Act, II Proc. Acad. Pol. Scr. 673, 68I (rg26), said:

"Just as it became necessary to the public welfare, in order that all men might live in peace, to restrain from fighting those whose individual self-control was not equal to the task of conforming to the requisite standard, so the Federal Trade Commission law stands as a declaration that the public welfare requires all business practices to conform to certain standards of fairness, honesty and impartiality, and that those who do not see eye to eye in these matters be restrained, to the end that honest men may do business honestly without fear or threat from dishonest practices directed into the maiket place, that integrity will not be crippled by corruption and that fair dealing may be the bond of trust between buyer and seller."

In the same publication, Mr. Gilbert H. Montague, in a paper entitled The New Policy and Procedure of the Federal Trade Commission, states at page 684:

"Mr. Rublee and I may sometimes have had differences as to what that act was intended affirmatively to do, but there was one thing we absolutely believed it was not intended to do, and that was to take jurisdiction over the petty cases of infringement of trade-marks, or misrepresentation in matters of that kind, and that it was not intended to duplicate the functions of the Department of Justice in the enforcement of the Sherman Anti-Trust Act. On those two subjects, we felt absolutely certain."

An interesting account of the early history of $\$ 5$ is offered by George Rublee, The Original Plan and Early History of the Federal Trade Commission, id. at 666, 669-670. 
cases in which the alleged violation of law is a "private controversy redressable in the courts." It is true, of course, that even in cases of this type the public interest may be indirectly involved, since some confusion as to sponsorship or reputation might have resulted from the respondent's use of the trade-mark on tableware. Such a minimum public interest, however, is involved in every conceivable case of trademark infringement or unfair competition. It can hardly be true, therefore, that any private controversy between a trade-mark owner and another party using his mark on unrelated goods involves a sufficiently substantial public interest to take the case out of the Commission's policy statement. Such a view, if generally accepted, would logically lead to the conclusion that any owner of a well-known trade-mark who may get tired of bringing infringement suits, or who may be disinclined to do so for financial reasons, may turn the matter over to the Commission, suggesting the institution of a cease and desist order proceeding and, in appropriate cases, if the defendant should have a trade-mark registered under the new Act, the bringing of a petition for cancellation of such mark under Section $I_{4}(d)$ of the Lanham Act. But it is particularly noteworthy in this respect that the provision of Section $\mathrm{r}_{4}$ (c) conferring jurisdiction on the Federal Trade Commission to bring cancellation proceedings refers only to sub-sections (a), (b), and (c) of Section 2, and makes no mention whatsoever of Section $2(\mathrm{~d})$. This in itself would seem to create a strong inference that the issue of likelihood of confusion with a previously registered mark was not considered by Congress to be among the grounds on which a cancellation proceeding on behalf of the public interest should be instituted. ${ }^{52}$

It is not the purpose of this article critically to examine the scope of the Commission's jurisdiction under the public interest clause of its organic act. The question we are here concerned with is simply this: If the use by another of the "Lady Esther" trade-mark on unrelated goods may not only injure the trade-mark owner's reputation or good will but-according to the Commission's findings-involves a substantial public interest, then would it not seem to be the duty of the Patent Office, which acts as the guardian of that interest, to refuse an application by such newcomer ex parte? In other words, would the Office fail in its duty toward the public if it passes to publication an application for "Kodak" for candy, or "Lady Esther" for neckties, or the like?

It is submitted that even in the light of the public-interest concept as applied by the Federal Trade Commission in the Lady Esther case, the Patent Office should

\footnotetext{
62 It may be noted in passing that a proper demarcation of public as compared with private interest is further obscured by $\$ 43$ of the Lanham Act, which now gives a private cause of action to any person whose interests may be adversely affected by misrepresentations or use of false designations of origin. While there has been no direct adjudication under this section thus far, Judge Clark in the rccent California sportswear case (California Apparel Creators v. Wieder of California, 162 F. 2d 893 (C. C. A. 2d 1947); cf. Annotation, X74 A. L. R. 496; Notes, 48 Col. L. Rev. 158 (1948); irg N. X. L. J. 1501, col. I, Apr. 23, I948; 26 TEx. L. Rev. 355 (1948); 28 B. U. L. Rev. 80 (1948)) involving a class suit by a number of manufacturers against misuse of the word "California" on sportswear not originating in that state, observed that such class suits might perhaps be properly instituted under $\$ 43$ of the Lanham Act. Cf. Callmann, False Advertising as a Competitive Tort, 48 CoL. L. Rev. 876 (1948).
} 
not ordinarily reject such applications ex parte under a theory of guarding the public against deception. Since our registration statute specifically provides several remedies which may be pursued by a party injured or damaged by a proposed registration, it would seem to be the safer course and more in line with the basic structure of the Act not to appear as vicarious avenger for the public's rights but to invite opposition and objections by those whose "reputation" or good will may be injured. Certainly the interest of the trade-mark owner against "dilution" of his mark is of no immediate concern to the public in general. Somewhat less remote but still legally almost indiscernible would be the interest of the public in protection against use of the name "Esquire" on socks, or "I7" on women's dresses. It should not be overlooked in this regard that the Federal Trade Commission in issuing orders in cases like the Lady Esther case proceeds on the basis of a record which must contain evidence, usually in the form of oral testimony, bearing out the Commission's conclusion that some segment of the public may have been actually confused. The Examining Corps of the Trade-Mark Division in examining a new application does not proceed on the basis of any record; nor is there an opportunity afforded to those whose interests may be most vitally affected to raise objections or offer evidence of likelihood of confusion. In other words, the examiner would have to base his conclusion as to a possible adverse effect on the public entirely on his own personal judgment. This may not be too hazardous if nationally known trade-marks such as "Vaseline," "Kodak," or "Hershey" are involved; but there may be hundreds of other marks which are equally well known to certain specialized business interests or groups without being within the immediate sphere of knowledge of the examiner. ${ }^{83}$

The conclusion would seem to be inescapable, therefore, that even under the broad confusion test of Section 2(d) of the new Act, applications involving possible confusion as to sponsorship or reputation should not be rejected ex parte on the ground of an ever present parallel interest of the public to be protected from this type of confusion. It seems that for the purpose of registration proceedings the private interests of the previous registrant are primarily involved and that the public interest in such situations is not sufficiently predominant to compel the Office to reject the application in its capacity as guardian of the public interest and irrespective of the previous registrant's own attitude.

However, we should perhaps recognize one possible exception to this rule: In some instances, an applicant's purpose of capitalizing upon a well-known trademark's uniqueness and reputation appears to be so obvious from the face of the application that an ex parte rejection would appear to be not only justifiable but

ws The hazards of official notice in administrative proceedings are pointed out in a challenging recent article by Professor Kenneth Culp Davis, Official Notice, 62 HArv. L. Rev. 537 (1949). In England, too, even the courts are reluctant to take judicial notice of the celebrity of certain trade-marks or names. Thus Mr. Justice Harman, in the recent case of Rolls Razor Ltd. v. Rolls (Lighters) Ltd., 66 Rep. Pat. Cas. 137, I39 (1949), said with regard to the name "Rolls-Royce": "It would, however, be an affectation not to admit that even a judge may have heard of 'Rolls-Royce." " 
the only appropriate action. In cases of that kind it would not be necessary for the Patent Office to rely on the prohibition of Section 2(d) alone. Under Section 2(a) of the Act, the Office not only may but must reject a mark which "... falsely suggests a connection with persons, living or dead ..." Where an applicant adopts famous words or marks such as "Lucky Strike," or "Hershey," or "GE," or "Ford" for goods other than those for which these various marks have been registered, such adoption of the marks alone may not necessarily and under all circumstances create a likelihood of confusion. But where, in addition to adopting such words, an applicant copies a peculiar design or script which is in current use by the previous registrant, the Office would clearly be justified in rejecting the application ex parte on the ground that the mark "falsely suggests a connection" with an existing business or corporation. To revert once more to the Lady Esther case: If in the case before the Federal Trade Commission the respondent had actually used not only the name "Lady Esther" but the peculiar script in which the cosmetics manufacturer may be using the mark, then a rejection of a new application showing the identical mark and script or design could be justified under Section 2(a) of the new Act. But in the absence of such collateral aggravating circumstances, an application to register the words "Lady Esther" for merchandise as different as tableware and cosmetics should be published even under the new Act so as to put the burden of proving damage or an adverse effect on the public on the previous registrant rather than on the Patent Office.

It should not, of course, be assumed that the private interest or attitude of a previous registrant should be permitted to prevail over a possible adverse public interest in situations where, in the judgment of the Commissioner, the registration of a mark applied for would clearly conflict with a prior registration and inevitably lead to confusion of the public. In other words, the Patent Office will always consider it its paramount duty to preserve and protect the "purity" of the register. For that reason, it is the established practice in the United States as well as in many other countries not to accept so-called "letters of consent" from previous registrants in cases in which registration would clearly run afoul of the prohibition contained in Section 2(d) of the Act. Thus, the Commissioner said several years ago:

There have been decisions holding that where the owner of a mark consents to its registra. tion to another, reasonable doubts with respect to the similarity of the goods involved should be resolved in favor of the applicant. However, the interests of the public may not be ignored; and when it appears that the goods are so nearly related that their sale under identical trade marks would be likely to confuse the public or to deceive purchasers, registration must be denied nothwithstanding the owner's consent. ${ }^{\text {ta }}$

"5e George A. Breon and Co. v. Aronovic, 33 U. S. P. Q. 390, 39 r (C. P. r937). (Italics supplicd.) The Court of Customs and Patent Appeals has frequently expressed the same view. It said in the leading case of In re Laskin Brothers, Inc., $\mathrm{r}_{4} 6 \mathrm{~F} .2 \mathrm{~d} 308,309$ (C. C. P. A. 1944): "The Commissioner of Patents acts as the guardian of the public interests and the parties by their deeds or agrcemcnt cannot confer upon him the power to do that which he is prohibited from doing under the statute." (Italics supplied.) Similarly, it was said in the earlier case of Skookum Packers Ass'n v. Pacific Northwest Canning Co., 45 F. 2d 9r2, 915 (C. C. P. A. 1930): "The mandate of the statute is plain, and partics cannot, by their conduct or by any agreement, confer upon the Commissioner of Patents the power to do that which the law forbids." Cf. also Gediman, The Public Interest Is Paramount, 27 J. PAr. Orp. Soc'y 634 (1945). 
On the other hand, where there may exist reasonable doubt in the examiner's mind because of differences in either the marks or the goods, or both, consent by a prior registrant should, and under recent practice usually will, have an important persuasive effect in determining registrability. In other words, the Patent Office may conclude that if the previous registrant would not consider himself injured by the application, there may be less likelihood that the general public would be confused. Such a liberal attitude toward the acceptance of letters of consent will very often avoid unnecessary contests between two or more parties who honestly believe that simultaneous use of their respective marks never has resulted and probably never will result in likelihood of confusion. The correct approach, it is suggested, is admirably stated in a recently published letter from the Canadian Registrar of TradeMarks, summarizing the applicable principles as follows:

If an application is filed for a mark identical or substantially identical to one appearing on the Register and for similar wares, the Registrar will not accept a consent by the registered owner as sufficient authority to enable the application to proceed to registration. The Registrar considers that in the interest of the public he must maintain the purity of the register. In such circumstances, the consent is considered to be tantamount to a licensing.

On the other hand, however, if the marks simply disclose a degree of similarity sufficient to raise a doubt in the Registrar's mind as to registrability, the Registrar will accept a statement by the registered owner that, in the opinion of the registered owner, the contemporaneous use of the mark sought to be registered and the mark appearing on the register in connection with the respective wares on which the marks are used, would not cause confusion in the market, as sufficient basis for the registration of the application. 55

The task of the Trade-Mark Division in initially passing on the registrability of a trade-mark as a matter of duty toward the public as well as the applicant could

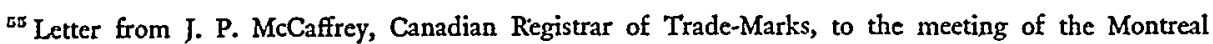
Branch of the Patent Institute of Canada, Feb. x, 1949; 9 Can. Pat. Rep. 51 .

The same principle prevails in Great Britain. Ever since the case of $I n$ re Dewhurst, 2 Ch. D. I37 $(1896)$, it is well established that consent by a prior registrant is an important factor for consideration since registration would; affect his interests most; but it is not considered conclusive or binding on the registrar. As a matter of fact, the British Patent Office and the courts have time and again stressed the importance of protecting the public interest in registration proceedings. Thus, Lord Macmillan observed in Bass, Ratcliff and Gretton, Ltd. v. Nicholson \& Sons, Ltd., 49 Rep. Pat. Cas. 88, Ir I (I932):

"There are obviously two main interests to be protected when a trade mark is presented for registration. There is first the interest of the public. A trade mark ought not to be registered if its use will be apt to mislead the public as to the origin of the goods they are purchasing. There is also the interest of other existing traders who are entitled to object if the use of the trade mark proposed for registration will be calculated to enable the applicant's goods to be passed off on the public as such other traders' goods. The statute is accordingly concerned to see that these interests are duly protected."

In one instance, the British court went so far as to say:

"In cases of alleged confusion the interests of the public are a more important consideration than the relative rights of the parties." In re Egg Products Lim's Application, 39 Rep. Pat. Cas. 155 (1922).

Lord Bowen, in Paine \& Co.'s T'ms, to Rep. Pat. Cas. 217, 232 (1893), has said: "The purity of the Register of Trade Marks is of much importance to trade in general, quite apart from the merits or demerits of particular litigants." And, in the famous Perfection case, Joseph Crosfield \& Sons, Ltd.'s Appl., 26 Rep. Pat. Cas. 837, 86r (r909), Farwell, L. J., said: "The question is not merely. one between the applicants and the opponents who appear before the tribunal; no agreement between them ought to influence such a tribunal." 
hardly be more succinctly defined than in the words of Lord Parker in one of the leading British cases:

The proper time for considering whether a mark is registrable, or whether, having regard to the interests of the public, it ought to be accepted or rejected, is, in my opinion, when the application for its. registration first comes before the Registrar under the twelfth section of the Act of 1905 . If the mark be then allowed to proceed to advertisement ... all possibility of considering whether, in the interests of the public or otherwise, it ought to be admitted to registration, may have been lost, for unless there be private opposition to the registration the mark must ... be put on the Register. ${ }^{56}$

\section{III}

\section{The Consideration of the Public Interest in Contested Cases}

\section{A. Cases Pending Before the Examiner of Interferences Or, on Appeal,} Before the Commissioner of Patents

I. As a general rule, Lord Parker's just-quoted admonition that the critical time for considering the public interest is the period before publication of the mark for opposition is of course, equally pertinent in the United States. In principle, publication in the Official Gazette is tantamount to a finding by the Office that registration of the published mark would not have an adverse effect on the public and that the application will mature into registration unless the private interests of a potential opposer might be damaged thereby. The primary issue to be then decided by the Examiner of Interferences or by the Commissioner on appeal is a determination of the respective private rights of two adverse parties, whether it be an issue of priority in an interference proceeding or a question of damage or injury in an opposition or cancellation proceeding. The Examiner of Interferences and the Commissioner, on appeal, thus act in a quasi-judicial capacity; and where the opposition or cancellation is based on a previously registered or used mark with which the published or registered mark may conflict, the issue of likelihood of confusion will be raised again, but will now be decided on the basis of evidence submitted by the parties. It thus becomes apparent that the interest of the public to be protected against likelihood of confusion may, and normally does, re-enter the picture at this stage, although under somewhat different circumstances. If, for instance, the trade-mark "Lady Esther" for shoes were passed to publication by the Office, as according to our previous discussion it should be, ${ }^{\text {b8 }}$ the owner of the well-known cosmetics mark might now for the first time raise the issue that confusion as to his reputation might result or that his well-known mark should be protected against "dilution." At this stáge the Office would not have to rely on facts of which it may or may not have official notice, such as the reputation of a famous trade-mark, but will afford the opposer an opportunity to build a record establishing the possibility of damage to his mark. Obviously, the extent and likelihood of such damage cannot in turn be determined without a finding on the part of the Examiner of Inter-

${ }^{s e}$ W. \& G. Du Cros., Ltd.'s Appl., 30 Rep. Pat. Cas. 660, 669-670 (19x3).

${ }^{s}$ Supra Part I. 
ferences that confusion of some sort on the part of the public is likely to result. But in reaching this conclusion, the confusion issue (or the priority issue in case of an interference) is resolved on the basis of proof of damage on the part of the opposer. Failing such proof, the opposition will be dismissed and the mark registered unless it is rejected ex parte on other grounds even at this stage of the proceeding. ${ }^{59}$

2. It becomes necessary then to re-examine the problem of likelihood of confusion and the concept of confusion itself as an inter partes rather than an ex parte issue. To put it differently: If we are correct in our previous assumption that even under the Lanham Act of 1946 confusion as to reputation or sponsorship or dilution of a mark is not the type of confusion which should ordinarily result in an ex parte rejection of a new application under Section 2(d), was it the intent and purpose of the new Act to give consideration to these types of confusion as an incident of an opthis broader confusion test underlies the structure of the new Act with regard to poser's damage or as a ground for cancellation? It can hardly be questioned that inter partes contests and that the elimination of all reference to. goods "of the same descriptive properties" will prove of far-reaching significance in connection with the determination of the confusion issue in opposition and cancellation proceedings. It is true, of course, that even under the old law the Court of Customs and Patent Appeals at one time at least had so emphasized the likelihood of confusion concept as to practically read the concept of "same descriptive properties" out of the Act. Thus, the court had said in the early leading case of B. F. Goodrich Co.v. Clive E. Hockmeyer: ${ }^{60}$

While it is true that the statute was not intended to be as comprehensive as the principles of equity applicable to the law of trade-marks, it certainly was not the purpose of the Congress to enact a statute opposed to those principles. To so hold would be but to deny that the statute was enacted in the light of common sense. Such a construction would require the registration of trade-marks which would not be recognized as legitimate by the courts under the substantive law of trade-marks. ${ }^{61}$

Even farther went the court's decision in the Three in One case, ${ }^{62}$ where the majority held an adhesive cement to have the "same descriptive properties" as an oil used as a lubricator or polish for metal. Significantly, the dissenting judge in that case expressed great concern over the court's alleged usurpation of equity powers and complete disregard of then existing statutory limitations, which should have

${ }^{20}$ See notes 83 and 84 infra.

${ }^{10}{ }_{40}$ F. 2 d 99 (C. C. P. A. $193^{\circ}$ ).

01 Id. at 103-104. The next step was taken in the line of cases beginning with the Elizabeth Arden case (Elgin American Mfg. Co. v. Elizabeth Arden, Inc., 83 F. 2 d. 68ז, 687 (C. C. P. A. 1936)), where it was held that soap and soap receptacles are "related" articles of commerce since they are sold at the same stores to the same class of people and are designed to be used together:

"It is true that they are not composed of the same materials. Many articles possessing the same descriptive properties, in a statutory sense, are not. The real question confronting us is whether the goods of the respective parcies are so related, commercially or otherwise, that, when marketed under the involved trade-marks, the purchasing public might reasonably conclude that they originated with the same coneern." Id. at 688.

82 Three in One Oil Co. v. St. Louis Rubber Cement Co., 87 F. $2 d 479$ (C. C. P. A. I937). 
prevented a holding of likelihood of confusion without a finding of "same descriptive properties." The following two paragraphs of the dissenting opinion are particularly noteworthy:

Reason as we may, think of the case as we will, the naked fact remains that the majority decision in the final analysis rests upon the proposition that the mark may be looked to in determining the question of "same descriptive properties" and notwithstanding the apparent recognition given the statutory phrase quoted, the decision in effect reads that phrase out of the statute. The decision means, and can mean nothing else, as I view it, that hereafter without any reference to the properties of the goods, this court will look to the mark, and if, in our judgment, the mark might create some sort of confusion, then it must follow that the goods are of the same descriptive properties.

I have never felt and do not now feel that such is a correct interpretation of the statute. Any trade-mark can be abused or misused. Both the common law and statutory law make provision for protection against abuses and misuses, and proper tribunals are provided in which to enforce remedies. It happens that this court has not so far been clothed with authority to enter the equity field. There are many very sound legal reasons why we should not try to force ourselves into it. ${ }^{63}$

When, however, an opposition was filed in 1936 by the owner of the magazine Better Homes and Gardens against registration of the words "Better Homes" for lawn grass seed, ${ }^{64}$ the court considered it necessary to retreat somewhat from the broad rule announced in the Three in One case, and restated its position in the following language:

A consideration of this line of cases, together with many others which might be cited, shows plainly the trend of authority so far as this court is concerned. It has never announced or intended to announce that it considered the words "the same descriptive properties" should be eliminated from the law. On the contrary, it has in all of these cases reiterated that the primary consideration was to ascertain whether the goods were or were not of the same descriptive properties. In this ascertainment, the rule has been liberalized so that all factors may be considered in ascertaining this fact. ${ }^{05}$

3. The Lanham Act, by eliminating any reference to the descriptive properties of the goods, has now given statutory recognition to a confusion concept which embodies not only the result reached in the Three in One case but, beyond that, enables the Examiner of Interferences to apply, wherever justified, prevailing equitable principles of the law of unfair competition. Under the new law, it will no longer be correct or necessary for the Office and its appellate administrative tribunal to proceed on the theory, as phrased by the dissenting judge in the Three in One case, that the Office "has not so far been clothed with authority to enter the equity field" and that it should not "try to force itself into it." On the contrary, if it should appear from the evidence that an applicant could be enjoined by the opposer in a court of equity on the usual grounds of unfair competition, the opposition should be sustained. While practically no inter partes cases involving this problem under the new

${ }^{\text {os } I d . ~ a t ~} 484$.

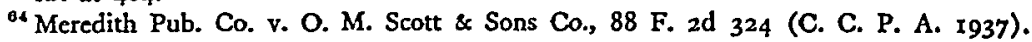

${ }^{65} \mathrm{Id}$. at 328 . 
Act have so far been decided by the court or even by the Commissioner, some of the more recent determinations by the Examiner of Interferences and by the Commissioner, even though technically still under the old Act, clearly indicate a realization of this new trend. Let us glance, for instance, at the recent case of Junior Guild Frocks, Inc. v. Page \& Dixon Drug Co., Inc., ${ }^{66}$ involving, inter alia, the question whether the owner of the trade-mark "Junior Guild" for women's dresses could cancel registration of the same mark for cosmetics. Under the peculiar facts there involved, the Commissioner found that even under the old Act, women's dresses and cosmetics might be considered "goods of the same descriptive properties." $\mathrm{He}$ then observed:

It is to be noted that the Trade Mark Act of I946 has eliminated the phrase "goods of the same descriptive properties" from the corresponding section of that Act (Sec. 2(d) of the Trade Mark Act of I946) apparently making the likelihood of confusion or mistake or deception of customers the only test. While that Act does not apply to this case, the omission is considered significant as indicating the emphasis which has been, and must be placed upon the existence of likelihood of confusion. ${ }^{67}$

It would seem that under the new Act there can be little doubt that in view of the well-known custom of dressmakers to add a cosmetic line to their products, the public would be likely to be confused as to sponsorship or reputation if the identical mark appeared on both lines of goods.

It may be even more interesting to speculate on what the outcome might have been under the new law of a motion to dismiss an opposition recently filed by an applicant for registration of the word "Swift" against the well-known meat packing concern, which relied on its registrations for "Swift" and "Swift's" for meat, soap, and cleaning powder. The theory of the opposition was that members of the public upon seeing the word "Swift" on a weighing scale in a butcher shop might erroneously connect the meat packer with the manufacturer of weighing scales and that, if the weighing scales were inferior, this might reflect on the opposer's reputation. The Commissioner felt constrained to grant the motion to dismiss on the ground that, under the old Act of I905, "there must come a point at which goods are so different that they cannot be considered goods of the same descriptive properties as a matter of law." It would seem that under the new law the motion to dismiss would have to be denied under such circumstances, since it may not well be maintained that use of the word "Swift" on weighing scales may not cause confusion as to source or sponsorship as a matter of law. In other words, the opposer should at least be afforded an opportunity under the new Act to offer proof as to possible damage to his reputation or as to the origin of the goods, or-in exceptional cases-possibly damage from "dilution" of his famous mark. It was this realization which led the Examiner of Interferences in a recent

${ }^{\circ} 79$ U. S. P. Q. 4 I (C. P. 1948).

${ }^{07}$ Id. at 45.

${ }^{\circ 8}$ Swift \& Company v. B. \& P. Swift, Ltd., 8o U. S. P. Q. 594 (C. P. 1949). 
case $^{69}$ to deny a motion to dismiss by an applicant for registration of the word "Alligator" for tobacco as against an opposer who alleged that the applicant's mark should not be registered over his well-known trade-mark "Alligator" for raincoats. Whatever may be the final adjudication on the merits of such a case, the broad confusion test of the new Act would certainly seem to entitle the opposer at least to submit his evidence and prepare a record.

The lack of uniformity among the various jurisdictions with regard to the availability and scope of equitable relief in cases involving confusion as to sponsorship or reputation will, of course, be a considerable handicap to the Patent Office tribunals in passing on these issues. Only recently one federal court of appeals found no confusion between the mark " $\mathrm{V}-8$ " as used on a vegetable cocktail on the one hand, and the name "VA" for tomato juice and similiar products on the other," while only a short time before another court of appeals had held the owner of the "V-8" trade-mark entitled to enjoin use of the same mark for vitamin tablets." Should the Office follow the most recent and rather liberal decision by the Court of Appeals for the Ninth Circuit in Safeway Stores, Inc. v. Dunnell, ${ }^{72}$ where in a 4915 proceeding the Safeway grocery stores were not only held entitled to oppose registration of applicant's "Safeway" mark as used on toilet seat covers, but were actually granted an injunction as a result of a counterclaim against continued use of the mark on seat covers?73 Or should the Office be guided by the narrow view of the Sunkist case, ${ }^{74}$ denying a reasonable likelihood of confusion even under the new Act between fruit and raisin bread? However individual contested cases of this kind may be decided by the Commissioner, it cannot be denied that he clearly has the authority under the new Act to give due consideration to all such equitable considerations regardless of whether or not he may feel justified in exercising such authority in the individual case. ${ }^{75}$

4. Interesting and difficult questions of a possible conflict between broad equities and the principle of maintaining the purity of the register are bound to arise in connection with two other innovations of the Act of 1946 which have found little adjudication so far: The recognition in Section $2(\mathrm{~d})$ of so-called "concurrent" registrations and the provision in Section. I9 admitting the equitable principles of laches, acquiescence, and estoppel in all inter partes proceedings (including those which were pending when the new law became effective).

\footnotetext{
${ }^{\circ}$ The Alligator Co. v. Larus \& Bro. Co., Opposition No. 27,915, motion to dismiss denied, Nov. 26, 1948.

${ }^{70}$ Standard Brands, Inc. v. Eastern Shore Canning Co., 172 F. 2d 144 (C. C. A. 4th 1949), cert. denied, I74 U. S. L. Week 3360 (June 7,1949 ).

${ }^{11}$ Standard Brands, Inc. v. Smidler, 55 I F. 2d 34 (C. C. A. 2d 1945). Cf. Comment, The Extent of a Trade-Mark Owner's Rights with Reference to the Kind of Goods, 35 T. M. Rep. 103 (1945).

7280 U. S. P. Q. 115 (C. C. A. 9th I949).

73 The case is now pending before the Supreme Court on petition for certiorari.

"Supra note 17 .

${ }^{75}$ That the Commissioner may apply such equitable principles of unfair competition secms even clearer now in the light of the just decided case of S. C. Johnson \& Son v. Johnson, supra note $16 b$, although that was an infringement case and did not directly pass upon the scope of the Commissioner's jurisdiction in inter partes cases.
} 
a. As construed by the Patent Office in the only case so far adjudicated by the Commissioner, the concurrent-use provision can only be invoked if the applicant's date of first use precedes the filing date of a pre-existing 1905 or I88I registration. This is not the place to examine the highly controversial question to what extent, if any, common law rights may have been validly acquired in commerce by an applicant subsequent to a registration under the 1905 Act. ${ }^{76}$ Our problem here concerns that part of Section 2(d) which makes it incumbent upon the Patent Office to deny a concurrent registration even to an otherwise qualified applicant if confusion or mistake or deceit of purchasers is likely to result "from the continued use of said marks ..." Under the present structure of the new Act, a preliminary finding by the Examiner of Trade-Marks of lack of such likelihood of confusion is a prerequisite to instituting a concurrent-use proceeding. It then becomes the major and controlling issue in an inter partes proceeding before the Examiner of Interferences. It would seem, however, that the approach toward a finding of confusion which will in turn result in a denial of the application for concurrent registration should be somewhat different from that normally applied. The statute itself invites a distinction by putting the emphasis on the "continued use" by both parties. This language lends significance to the fact that the two marks may actually have been used side by side for a number of years without any actual confusion. In the normal registration proceeding, such past events bear little, if any, weight, since a determination of "likelihood" of confusion involves speculation with regard to prospective consequences rather than an equitable consideration of past practices. In other words, situations may well arise under Section 2(d) in which the Office might ordinarily find a likelihood of confusion as an abstract proposition but wherein this possible adverse effect on the public and on the purity of the register would appear outweighed by the special circumstances of a lawful concurrent use. Where a court has found such lawful use, the Patent Office is, of course, bound under the proviso of Section 2(d) to conform its register to the court decree. But it cannot be denied that the new law gives the Commissioner himself the authority to make such a finding in proper cases. Even in Great Britain, where, as previously noted, ${ }^{77}$ the interest of the public and the purity of the register are jealously guarded by the Patent Office, the courts, including the House of Lords, have recognized that in proper cases of an honest concurrent user and other "special circumstances" the purity of the register may have to be sacrificed for the purpose of recognition of special equities. Thus, it was stated by Sargant, J., in the case of Maeder's Application:

Then what is the effect of the section? It seems to me that it gets rid of the prima facie disability imposed on the registering authority by section 19 , and enables a trade mark which is either identical with an existing trade mark or is nearly identical with

${ }^{70}$ March, supra note I; Halliday, Concurrent Registrations Under the New Trade-Mark Law, 37 T. M. Rep. 243 (1947).

${ }^{77}$ Supra note 55 . 
an existing trade mark to be registered in the case either of honest concurrent user or other special circumstances; that is to say, it, in my opinion, relaxes the strict rule which had otherwise bound the registering authority under the previous legislation in a certain limited class of cases. It seems to me that the intention was to allow the Court to weigh against a slight possibility of deception, or a slight possibility of confusion, in the minds of the public, the commercial claims which a proprietor of a common law trade mark might have acquired through a considerable amount of concurrent user. ${ }^{78}$

If the concurrent use provisions of the new Act are to have any practical value, the Office will have to be similarly lenient in cases of applicants who meet all other qualifications of the Act but whose continued use of the mark and its registration might lead to such "slight" possibility of confusion in the minds of the public.

b. A similar situation might conceivably arise in cases in which under the new Act an applicant is permitted to raise the defenses of laches, acquiescence, or estoppel. Where, for instance, an opposer has not only silently permitted an applicant to build up a substantial business under a mark but may have affirmatively encouraged the applicant to do so, the latter may be held entitled to a registration even though under normal circumstances the application would be rejected ex parte on the ground of likelihood of confusion under Section 2(d). This, however, would only be true in situations in which-to quote Judge Learned Hand in the White House case-70 "the owner may have so conducted himself as impliedly to assure the newcomer that he does not object, and the newcomer may have built upon that assurance."

It is, of course, well settled that mere delay does not deprive the trade-mark owner of his right to a permanent injunction even though he may lose the right to a preliminary injunction or to an accounting of profits. ${ }^{80}$ It would follow, therefore, that even in cases of laches an opposition might have to be sustained as long as the opposer would still be in a position to secure permanent injunctive relief against the applicant in a court of equity. Along this line of reasoning, it was held by Assistant Commissioner Daniels in the recent case of Kroger Grocery \& Baking Company v. Country Gardens, Inc., ${ }^{81}$ that an opposition by the owner of the mark "Country Club" for canned food against registration of the words "Country Garden" for canned vegetables had to be sustained because the opposer had not so conducted himself as actually to be deprived of his right to an injunction in an equity court. The Commissioner held in effect, therefore, that the interest of the public in the purity of the register and the prohibition against registration of confusingly similar marks under Section 2(d) outweighed the considerable equities on which the appli-

${ }^{78} 33$ Rep. Pat. Cas. 77 (Igr6). (Italics supplied.)

${ }^{70}$ Dwinnell-Wright Co. v. White House Milk Co., 132 F. 2d 822, 825 (C. C. A. 2d 1943).

${ }^{80}$ In the most recent federal decision involving the defense of laches and acquiescence, Greyhound Corp. v. Rothman, 8r U. S. P. Q. 185 (D. Md. 1949), Judge Coleman observed that the passage of time was not as important as the circumstances surrounding it and that delay in protesting or acquicscence implied by silence must be accompanied by other circumstances in order to constitute ground for denial of injunctive relief. In granting an injunction against fraudulent use of the name "Greyhound," Judge Coleman relied on the oft-quoted statement by the Supreme Court in Menendez v. Holt, 128 U. S. 514 , 523 (1888): "Mere delay or acquiescence cannot defeat the remedy by injunction in support of the legal right, unless it has been continued so long and under such circumstances as to defeat the right itsclf."

s1 76 U. S. P. Q. 542 (C. P. 1948 ). 
cant sought to rely. It is suggested, however, that, in a case in which the equities of an applicant are so strong as seriously to impair or vitiate the opposer's possible right to equitable relief, the Commissioner would be justified in granting the applicant's registration on the theory so well expressed in the above-cited British case, that under such special circumstances some "slight" confusion in the mind of the public may have to be condoned as a matter of special justice to the applicant. ${ }^{82}$

5. As a general rule, the Trade-Mark Division "loses jurisdiction" over the application once it is passed to publication. Where, however, reasons become known after the mark has been published for which the mark should have been rejected ex parte, the Examiner of Trade-Marks may ask the Commissioner for "jurisdiction" in order to reject the mark ex parte even after it has been published for opposition and even though no opposition may have been filed. This usually happens in situations in which it subsequently comes to the attention of the Division that the mark may actually be generic or otherwise unregistrable, so that the public interest would be adversely' affected if the application were permitted to mature into registration. Under the prevailing rules of the Office, such a request may be made by the Examiner of Trade-Marks even after an inter partes proceeding has been instituted. ${ }^{83}$ Such a finding of unregistrability ex parte may not only be made by the Examiner of Trade-Marks, but by the Examiner of Interferences as well and even by the Commissioner on appeal from inter partes decisions by the Examiner of Interferences. The cases are quite numerous, therefore, in which either the Examiner of Interferences or the Commissioner himself has acted as "guardian of the public interest" and rejected a mark ex parte regardless of whether the ex parte ground formed a part of the issues raised by the opposition or interference or not. As a

${ }^{83}$ For a more detailed discussion of the problems arising from the application of $\$ 19$, cf. Derenberg, Equitable Defenses in Patent Office Proceedings 38 T. M. Rep. 495 (1948). It is sometimes argued that the new Act has changed the established rule under which the validity of an opposer's registration is not in issue in an opposition proceeding unless a counterclaim for cancellation is filed. This rule, which is based on sound considerations of public policy, continues to prevail under the new Act. But, as suggested in the above-mentioned paper, it should perhaps not be so strictly applied as to deprive an applicant of the opportunity of showing the weakness of the opposer's mark or parts thereof. In other words, third-party registrations may well be given added consideration in inter partes proceedings not as a matter of equitable defense nor as an attack on the validity of the opposer's mark, but simply as a circumstance having a sometimes decisive bearing on the issue of likelihood of confusion. Thus, where an applicant desires to have published a mark beginning with the letters "veg" for canned vegetables or "vita" for vitamins, the fact that there may be many other registrations beginning with such letters should certainly be a persuasive factor in determining likelihood of confusion between the applicant's and the opposer's marks, in cases wherein the opposition is based on a mark beginning with the same letters. Kraft Walker Cheese Co. v. Kingsland, 75 F. Supp. ro5 (D. D. C. 1947). Cf. also Jenney, A Plea for Realism in Trade-Mark Oppositions, 29 J. PAT. OFF. Soc'y 668 (1947).

Any further discussion of these problems is, however, deemed outside the scope of this paper.

${ }^{3}$ Rule 24.3 specifically provides as follows:

"If, during the pendency of a contested or inter partes case, facts appear which in the opinion of the Examiner of Trade-Marks render the mark of any applicant involved unregistrable, the attention of the Examiner of Interferences shall be called thereto. The Examiner of Interferences may suspend the proceeding and refer the case to the Examiner of Trade-Marks for his determination of the question of registrability, and the proceeding shall be dissolved or continued in accordance with such determination. The consideration of such facts by the Examiner of Trade-Marks shall be inter partes." Rures of Practice in Trade-Mark Cases (U. S. Dep't of Commerce, I948). 
matter of fact, the Court of Customs and Patent Appeals has emphasized on many occasions that it is not only the right but the duty of the Patent Office tribunals to reject pending applications on ex parte grounds regardless of whether such grounds are brought to the attention of the Examiner of Commissioner by the adverse party to the proceeding. ${ }^{84}$ Where such an ex parte ground is raised by an opposer, but the opposer fails to satisfy the Examiner that he would be damaged by the proposed registration, his opposition will be dismissed but the mark rejected ex parte. This most frequently happens in cases where the opposer does not rely on a previous registration but on the ground that the mark sought to be registered is generic, descriptive, or otherwise invalid. Unless the opposer can show that he himself would be damaged in view of his own use of the word in a generic or descriptive sense, his opposition will be dismissed even though the application may be rejected ex parte. This distinction between sustaining an opposition as an inter partes matter but on a ground -which would have also justified an ex parte rejection and a dismissal of an opposition with simultaneous rejection of the application ex parte, assumes considerable importance at a later stage of the proceeding if the dissatisfied applicant should decide to institute an equity action under Section $4915 .{ }^{85}$ It is sufficient for our present purposes to emphasize that the public interest in keeping off the register marks whose registration would violate any one of the prohibitions of Section 2 stays with the application as long as it is within the jurisdiction of the Commissioner himself. However, grounds such as likelihood of confusion as to sponsorship or reputation are not and should not be among the ex parte grounds on which the Examiner of Interferences or the Commissioner on appeal should reject the mark. As previously pointed out, these issues predominantly affect the private interest of the opposing party rather than the interest of the general public. ${ }^{80}$

\footnotetext{
${ }^{84}$ Englander v. Continental Distilling Co., 95 F. 2 d 320 (C. C. P. A. 1938); Frankfurt Distilleries, Inc. v. Dextora Co., I03 F. 2d 924 (C. C. P. A. 1939).

${ }^{86}$ The jurisdictional problems here arising will be considered further infra, Part IV.

${ }^{\text {so }}$ Supra, Part I. There was a strange inconsistency under the old practice with regard to the cffect of an opposer's failure to plead the corporate-name clause of the Act. Although under $\$ 5$ of the Act of 1905 the adoption of somebody else's entire corporate name was listed among the grounds on which the Office was bound to reject a new application, the Office and the Court of Customs and Patent Appeals always proceeded on the theory that this clause had to be specially pleaded by the opposcr and that failure to plead it would result in a "waiver" on the opposer's part. This practice seems difficult to justify from the public-interest point of view. It also frequently led to rather anomalous results. Thus, in the most recent case of Tidy House Products v. Tidy-House Paper Products Co., 80 U. S. P. Q. 526 (C. P. 1949), the opposition by the Tidy House Products Company to registration of the words "Tidy House" was sustained with regard to use on paper towels, paper napkins, and similar articles on the ground that the words were the opposer's entire corporate name and regardless of the difference in properties of the articles involved; while, on the same day, an opposition by the same party was dismissed with regard to other paper household products such as garbage bags, paper cups, ctc., because opposer had failed specifically to raise the name clause and was therefore considered to have "waived" it. 80 U. S. P. Q. 527. From the viewpoint of the public and that of the "purity of the register," the applicant's error in one of these cases specifically to plead the "name clause" of 55 of the old Act should hardly have led to different decisions in the pending opposition proceedings.

In the Swift case, supra note 68, the opposer had also failed specifically to plead the name clause. The Commissioner refused to consider the point ex parte.
} 
B. Cases Pending Before the Court of Customs and Patent Appeals

It goes without saying that any decision in an inter partes case by the Examiner of Interferences or by the Commissioner on appeal which is based on or involves ex parte considerations and is appealed to the Court of Customs and Patent Appeals will be reviewed by that court in the last instance. Thus, to mention only one recent case, $^{87}$ the court held that in an opposition proceeding involving an application of the word "Telecolor" it became unnecessary to rule upon the likelihood of confusion between that mark and the opposer's "Technicolor" because the Patent Office tribunals had rightly held that "Telecolor" should be rejected ex parte as being either descriptive or misdescriptive. The court, therefore, affirmed the Patent Office on the ex parte ground of descriptiveness without even considering the applicability of the so-called "name clause" of the Act of rgos or the question of likelihood of confusion between "Technicolor" and "Telecolor" as applied to radio receivers on the one hand and motion picture color film on the other.

But a more difficult problem arises when the Patent Office tribunals, after due consideration of all possible ex parte considerations for rejection, whether they are raised by the opposer or not, reaches the conclusion that the mark is registrable. If in such cases the opposition is dismissed for failure of the opposer to show injury, may the opposer upon appealing to the Court of Customs and Patent Appeals challenge the correctness of the Patent Office's ex parte ruling? In other words, should the Court of Customs and Patent Appeals act as the guardian of the public interest and reconsider on its own motion or upon suggestion by the unsuccessful opposer the correctness of the Patent Office's determination that the mark sought to be registered was actually registrable under the statute? This question was squarely presented to the court in the recent case of Revere Paint Company v. Twentieth Century Chemical Company, ${ }^{88}$ and answered in the negative by a majority of the court. The suggestion that the court should consider the ex parte issue on its own motion in order "to safeguard the public interest" was rejected with the curt statement that it was "so obvious as to require no discussion" that the court had no such authority. In a strong dissenting opinion, Judge O'Connell expressed the view that the court as well as the Commissioner of Patents has a duty to safeguard the public interest and that, consequently, the court had jurisdiction to hold the mark unregistrable as a matter of public interest and regardless of the assigned reasons for appeal or the contentions of the parties. However, since the decision in the Revere case, it must be considered established law that the Court of Customs and Patent Appeals will not act as guardian of the public interest unless it can do so in the exercise of its statutory reviewing authority. It follows that an unsuccessful opposer is barred from acting as vicarious defender of the public interest after the Commissioner of Patents has held the mark registrable, since in that event the ex parte issue of registrability is

\footnotetext{
${ }^{\text {s7 }}$ Columbia Broadcasting System v. Technicolor Motion Picture Corp., 166 F. 2d 94I (C. C. P. A. I948).

${ }_{88}{ }_{150}$ F. $2 d 135$ (C. C. P. A. 1945).
} 
not deemed to be within the statutory jurisdiction of the administrative appellate tribunal.

\section{IV}

\section{The Commissioner of Patents as Guardian of the Public Interest in Equity Proceedings Under Section 4915 of the Revised Statutes}

We now come to the consideration of the last and-until the enactment of the Lanham Act-the most confused and unsatisfactory phase of our problem: Under what circumstances and to what extent does the Commissioner of Patents act as guardian of the public interest when made a defendant or co-defendent in an equity action under Section $4915^{?^{89}}$ And is it really true, as suggested by Judge O'Connell in the Revere case, ${ }^{90}$ that it makes no difference from the viewpoint of protecting the public interest "whether the action of the Commissioner of Patents taken of his own motion is technically described as an ex parte or an inter partes decision"? It is submitted that it indeed does make a difference whether the decision appealed from was an ex parte rejection or involved an adjudication of the respective rights of two or more private parties. Failure to recognize this distinction under the Act of 1905 has led to an almost incredible state of confusion among the various courts and has resulted in the necessity in recent years of bringing parallel actions against both the successful opposer and the Commissioner of Patents in the District of Columbia and in the district in which the successful opposer is located. ${ }^{01}$ At least, in one very recent case the plaintiff's action in the District of Columbia was dismissed on the ground that the successful opposer was not subject to the jurisdiction of the court and that the suit could not proceed against the Commissioner alone, while the plaintiff's simultaneously filed suit in the Third Circuit was dismissed there on the theory that the successful opposer could not be sued alone without joining the Commissioner as a party. ${ }^{92}$ Consequently, the result would be in such cases that the plaintiff actually finds himself out of court altogether. Both the successful opposer and the Commissioner have been labeled in various conflicting decisions at one time as "adverse party," then as "proper party," then as "necessary party," then as "indispensable party," without the courts' ever reaching an actually fair and workable solution. Thus it was held-to mention only a few leading cases-in Century Distilling Company v. Continental Distilling Company ${ }^{93}$ that only the successful opposer and not the Commissioner of Patents was an indispensable party to a

\footnotetext{
${ }^{80}$ O'Brien, Trade Mark Cancellation and Opposition Proceedings and the R. S. 49r5 Remedy, 24 J. PAt. Off. Soc'y 42 (1942).

${ }^{\circ}$ Stupra note 88 , at $14 x$.

${ }^{01}$ Cf. for instance, Speed Products Co. v. Tinnerman Products, Inc., 73 U. S. P. Q. I81 (S. D. N. Y. 1947); Speed Products Co. v. Kingsland and Tinnerman Products, Inc., 77 U. S. P. Q. 447 (App. D. C. 1948); and the still pending cases of Warsaw Brewing Corp. v. Kingsland and Atlantic Brewing Co. (N. D. Ill., Civil No. 48C 1662); Warsaw Brewing Corp. v. Kingsland and Atlantic Brewing Co. (D. D. C., Civil No. 462I-48); Botany Worsted Mills v. S. L. Peacock (D. N. J., Civil No. I 4479 ), and Botany Worsted Mills v. Commissioner of Patents (D. D. C., Civil No. 2746-48).

${ }^{02}$ Botany Worsted Mills v. S. L. Peacock (D. N. J., Civil No 11479 ) (still pending).

${ }^{03}$ 106 F. 2d 486 (C. C. A. 3d 1939).
} 
4915 proceeding involving an issue of confusion between the mark applied for and the opposer's previously registered mark. Since there was "an opposing party" it was held that a copy of the bill need not be served on the Commissioner under the very language of Section 49r5, and that he was not, therefore, a necessary party. In Drackett Company v. Chamberlain Company, ${ }^{94}$ on the other hand, the Commissioner had sustained an opposition on the ground of the mark's descriptiveness and an equity suit was brought against the successful opposer in his jurisdiction without joining the Commissioner of Patents. The court there said:

The Commissioner of Patents is an essential party in any contest concerning the descriptive character of the respective trade marks in suit. That essential party defendant is lacking in the instant case and of necessity cannot be made a party defendant in a jurisdiction in which he is a nonresident. ${ }^{\text {} 5}$

Contrariwise, it was held in $7 . C$. Eno (U.S.) $L t d . v . C o e^{96}$ that a suit under Section 4915 cannot proceed against the Commissioner of Patents alone where the action seeks cancellation of a registered mark allowed by the Commissioner just prior to the institution of the suit. In distinguishing its own previous decisions, the court stated that a party who has been successful in a Patent Office interference or opposition proceeding is an indispensable party to a suit which seeks to cancel his mark. This was stated to be "an elementary and obvious matter of due process." Shortly before the Eno case, the same court had held in the Hobart case ${ }^{97}$ that the Commissioner is not an "adverse party" to a suit brought under Section 4915 by a defeated applicant for a patent or trade-mark. In the Eno case, the court expressly stated that the validity of a trade-mark cannot be litigated in a suit against the Commissioner of Patents to which the owner of the mark is not a party. However, when the question subsequently arose whether the Commissioner could be sued alone and was a "proper party" in a situation where an opposition had been sustained because of likelihood of confusion with a previously used trade name, the same court held that such an action may proceed in the District of Columbia against the Commissioner of Patents alone.98 The court there refused to distinguish between ex parte issues upon which the Commissioner may refuse to register a mark as a matter of public interest and inter partes cases in which he acts in a quasi judicial capacity adjudicating the rights of opposing parties. "No such line of distinction can properly be drawn. Presumably the Patent Office acts in the public interest in all cases, whether it grants or refuses the patent or trade-mark registration." ${ }^{\text {,99 }}$ The fact-continued the court-that the opposer called the Office's attention to the earlier "mistake" did not make the second decision any less an action in the public interest than if the Patent Office tribunals themselves had originally discovered it. More-

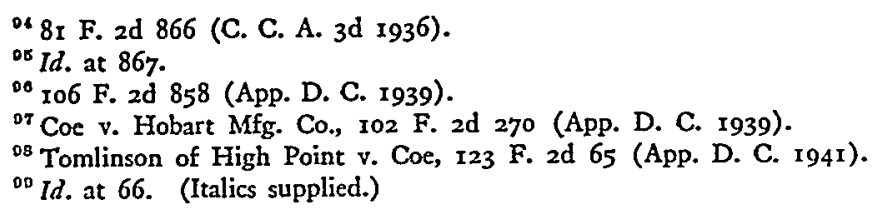


over, the court took the position that the opposer could not act to carry out a court decree authorizing registration and that the public interest could not properly be served without the participation of the Commissioner. ${ }^{100}$ In its most recent (and most drastic) decision on this point, which was rendered after the new law had become effective but involved a suit filed prior to the effective date of the Act, the court of appeals went so far as to say that only the Commissioner of Patents and not the successful opposer is an indispensable party to an equity action to set aside the Commissioner's decision sustaining an opposition. ${ }^{101}$ Here again, the Patent Office had found the applicant's mark registrable as an ex parte matter but subsequently sustained the defendant's opposition based on a previously registered mark, thereby in effect adjudicating that the opposer would be damaged by the registration. In an effort to clarify the entire problem, the court summarized what it considered to be the correct rule in the following paragraph:

In order, therefore, that there may be no dispute as to the holding of this case, we hold that the opposer is a proper but not an indispensable party in such an action under $\$ 4915$ and thus that the dismissal of this action by the District Court was improper, based, as it was, on the erroneous ground that the opposer in this case was an indispensable party. The rights of the opposer may be fully protected by his intervention if he desires to do so but the rights of the appellant should not be defeated by reason of the failure or refusal of the opposer to appear. ${ }^{102}$

If proper consideration of the public interest should actually require the conclusion reached by the court in the Barron-Gray case, we would have to accept the following anomalous results: (I) The very person who has functioned below as an adjudicator of a private contest between two parties would now become the sole defendant and only indispensable party. (2) A successful opposer or petitioner for cancellation or applicant in an interference proceeding would be compelled, no matter where located, to intervene as a voluntary defendant in the District of Columbia. (3) A decision by the Commissioner deciding, for instance, that one interfering applicant had priority over another or that an opposer would be damaged by a new

100 The court apparently overlooked the very language of the statute, which speaks in terms of "authorizing" the Commissioner to act and not in terms of directing him to do so. It has been well established since the early leading case of Vermont Farm Machine Co v. Marble, 20 Fed. 117 (C. C. D. Vt. $\mathbf{8 8 4}$ ), that is is not necessary to make the Commissioner a party defendant solely for the purpose of carrying out the mandate of the court. Said the court in the Vermont casc:

"It is further objected against the jurisdiction here that the court here could not compel obedience of the commissioner at the patent office to its decree. It is to be presumed, however, that a high officer of a department of the government will do his duty without compulsion, or even command, from any quarter, especially in a matter where he has no interest, nor the government any, except that the duty be done. This provision of the statute is framed according to this view." Id. at 118-119.

Moreover, 537 of the Lanham Act now gives broad power to the federal court to order registration or cancellation of trade-marks or otherwise rectify the register. Such decrees and orders, the section continues to provide, "shall be certified by the court to the Commissioner, who shall make appropriate entry upon the records of the Patent Office, and shall be controlled thereby." Under the theory of the Barron-Gray case, infra note Ior, and the Tomlinson case, supra note 98 , it would be necessary to join the Commissioner of Patents as a party defendant in an infringement suit in order to make certain that he will carry out the court's order!

101 Barron-Gray Packing Co. v. Kingsland, I7I F. 2d 576 (App. D. C. 1948).

${ }^{102}$ Id. at 578 . 
registration because of injury to the opposer's reputation or good will would have to be considered primarily as involving issues affecting the public interest rather than the private rights of such interfering or opposing parties.

It was to avoid and correct such a distorted view of the character of the Commissioner's decision in inter partes matters that Section 21 of the Lanham Act was enacted. This section now unequivocally states:

The Commissioner of Patents shall not be a necessary party to an inter partes proceeding under Revised Statutes 4915, but he shall be notified of the filing of the bill by the clerk of the court in which it is filed and the Commissioner shall have the right to intervene in the action.

The purpose of the new provision was clearly indicated by two statements made by former Assistant Commissioner Fenning and the late Assistant Commissioner Frazer during the hearings:

Mr. Fenning: I am suggesting that we do add in section $2 \mathrm{I}$ these words, "The Commissioner shall not be a party in inter partes cases." You see, when it is an inter partes case the partie themselves have fought in the Patent Office. The Commissioner has been the judge who has decided the case, and it would seem unreasonable to let the judge be the only party defendant. ${ }^{103}$

Mr. Frazer: We feel very strongly that the Commissioner of Patents should not be joined as a party in any inter partes 4915 case. We see no necessity for it. ${ }^{104}$

Section 2I of the Lanham Act is thus based on the realization that the vast majority of inter partes decisions adjudicating the respective rights between a registrant and a petitioner for cancellation, or those of an applicant and an opposer, or those between two or more interfering applicants, are adjudications of private rights which may at most incidentally affect the public interest. Hence, the rights of the victorious party in such proceedings are primarily at stake and a theory under which the Commissioner of Patents alone must respond to a complaint seeking to set aside his own adjudication would almost seem to refute itself. It would lead to a situation where the Commissioner in defense of his own adjudication of an issue of priority or damage would have to appear for and represent the only real party in interest, i.e., the successful opposer or other adverse party. It would seem clear, therefore, that in all cases falling under the provision of Section 2I of the new Act equity suits by any successful party to an inter partes proceeding should be brought only in the jurisdiction where the successful party is located and that the Commissioner should be merely "notified" of the filing of such action so as to give him an opportunity to intervene in appropriate cases. It would then be up to the Commissioner to intervene in cases which in his judgment involve an issue of public importance, such as, for instance, an issue of the alleged descriptiveness or genericness

${ }^{103}$ Hearings before the Subcommittee on Trade-Marks of the House Committee on Patents on $H . R$. 102, H. R. 5461, and S. 895, 77th Cong., xst Sess. 142-143 (1941).

10d Id. at 143. 
of the applicant's mark. In cases of this type not only the opposer but other members of the general public as well would be damaged by the proposed registration, so that the opposer really appears vicariously in the interest of all concerned. But where the Commissioner's adjudication in the inter partes case has the earmarks of a determination of such predominantly private issues as priority of use, damage to reputation, and many others, the public need not be represented in a subsequent equity action at all. In such situations, the stake of the public in the outcome of the litigation is no greater and no more immediate than that which is present in all civil trade-mark infringement or unfair competition litigation. The Commissioner of Patents need not and should not be called upon in the future to appear and act as guardian of such remote and inconsequential "public" interest. It is believed that the Lanham Act, by conferring upon the Commissioner a mere option to intervene in appropriate cases, has struck the proper balance between adjudications of private rights and cases involving a substantial public interest. 